University of Pennsylvania Carey Law School

Penn Law: Legal Scholarship Repository

Faculty Scholarship at Penn Law

2020

\title{
Defined Contribution Plans and the Challenge of Financial Illiteracy
}

\author{
Jill E. Fisch \\ University of Pennsylvania Carey Law School \\ Annamaria Lusardi \\ George Washington University \\ Andrea Hasler \\ George Washington University
}

Follow this and additional works at: https://scholarship.law.upenn.edu/faculty_scholarship

Part of the Adult and Continuing Education Commons, Business Law, Public Responsibility, and Ethics Commons, Education Policy Commons, Labor and Employment Law Commons, Law and Economics Commons, Law and Society Commons, Policy Design, Analysis, and Evaluation Commons, Public Policy Commons, and the Retirement Security Law Commons

\section{Repository Citation}

Fisch, Jill E.; Lusardi, Annamaria; and Hasler, Andrea, "Defined Contribution Plans and the Challenge of Financial Illiteracy" (2020). Faculty Scholarship at Penn Law. 2076.

https://scholarship.law.upenn.edu/faculty_scholarship/2076

This Article is brought to you for free and open access by Penn Law: Legal Scholarship Repository. It has been accepted for inclusion in Faculty Scholarship at Penn Law by an authorized administrator of Penn Law: Legal Scholarship Repository. For more information, please contact PennlawIR@law.upenn.edu. 


\title{
DEFINED CONTRIBUTION PLANS AND THE CHALLENGE OF FINANCIAL ILLITERACY
}

\author{
Jill E. Fisch $\dagger$ Annamaria Lusardi $\&$ Andrea Hasler $\dagger \dagger$
}

Retirement investing in the United States has changed dramatically. The classic defined benefit (DB) plan has largely been replaced by the defined contribution (DC) plan. With the latter, individual employees' decisions about how much to save for retirement and how to invest those savings determine the benefits available upon retirement.

We analyze data from the 2015 National Financial Capability Study to show that people whose only exposure to investment decisions is by virtue of their participation in an employer-sponsored 401(k) plan are poorly equipped to make sound investment decisions. Specifically, they suffer from higher levels of financial illiteracy than other investors. This lack of financial literacy is critical because of both the financial consequences of poor financial decisions and a legal structure that relies on participant choice to limit the fiduciary obligations of the employer with respect to the structure and options provided by the retirement plan.

In response to this concern, we propose mandated employer-provided financial education to address limited employee financial literacy. We identify and discuss three requirements that a financial education program should incorporate-a self-assessment, minimum substantive components, and timing. Formalizing the employer role in evaluating and increasing financial literacy among plan participants is a key step in providing retirement plan participants with the resources necessary to manage important decisions regarding retirement planning and, ultimately, for enhancing the financial security of American workers.

INTRODUCTION ........................... 742

I. The Evolution of Defined Contribution Plans ... 746

II. FidUCIARY LIABILITY FOR 401(K) PlANS . . . . . . . . . . . . 754

$\dagger$ Saul A. Fox Distinguished Professor of Business Law, University of Pennsylvania Law School \& Co-Director, Institute for Law \& Economics.

$\ddagger \quad$ University Professor of Economics \& Accountancy, The George Washington University \& Academic Director, Global Financial Literacy Excellence Center.

$\dagger \dagger$ Assistant Research Professor in Financial Literacy, Global Financial Literacy Excellence Center, The George Washington University School of Business. 
III. The Distinctive FinANCIAL Illiteracy OF WORKPLACEONLY INVESTORS . ................... 757

IV. IMPLICATIONS OF FINANCIAL ILLITERACY FOR 401(K) INVESTING . ..................... 772

V. IMPROVING RETIREMENT INVESTING THROUGH 401(K) Plans . . . . . . . . . . . . . . . . . . . . . . . . . . 777

A. Employer Responsibility as a Substitute for Employee Financial Literacy . ........... 778

B. Formalizing the Employer's Role in Evaluating and Remediating Financial Illiteracy by Plan Participants ......................... 780

1. The Importance of Financial Literacy for Appropriate Retirement Savings and Investment.................... 780

2. The Role of Financial Education in Improving Financial Literacy ................... 783

3. Key Components of Employer-Provided Financial Education ................... 785

\section{INTRODUCTION}

Retirement investing in the United States has changed dramatically. The classic pension plan, also known as a defined benefit plan, in which an employer paid a retired employee a fixed monthly benefit, is largely extinct. ${ }^{1}$ Instead, employers have overwhelmingly switched to defined contribution plans, commonly known as $401(\mathrm{k})$ plans, in which an individual employee's decisions about how much to save for retirement and how to invest that savings determine the benefits that the employee will have available upon retirement. ${ }^{2}$

The challenge with this system is that U.S. employees are poorly equipped to make decisions about how to invest for retirement. Retirement investing is complicated, the typical $401(\mathrm{k})$ plan offers participants products that many of them do not understand, and retirement saving is most effective when people begin saving early. In addition to the initial decisions, effective retirement investing requires plan participants to evaluate whether to make changes to their portfolios over the

1 See David E. Morse, Are Pension Plans Headed for Extinction?, 15 BenEFITS L.J. 1, 1 (2002) (describing the shift from defined benefit to defined contribution plans after the adoption of ERISA and the creation of the 401(k) plan).

2 The $401(\mathrm{k})$ plan is the product of changes made to the Internal Revenue Code by the Revenue Act of 1978 that shield retirement savings from federal income taxes. Revenue Act of 1978, Pub. L. No. 95-600, § 135, 92 Stat. 2763, 2785 (1978) (codified as amended at I.R.C. § 401(k) (2012)). 
course of their career and, when they retire, to determine how to manage the balance in their accounts to provide income for the rest of their lives. ${ }^{3}$

The complexity of appropriate retirement investing is compounded by the fact that financial literacy rates in the general population are low. ${ }^{4}$ People with low financial literacy are susceptible to a variety of investment mistakes, including choosing products that do not meet their needs and paying excessive fees. ${ }^{5}$ In addition, studies have shown that people who score lower in terms of financial literacy are less likely to plan for retirement, leaving those who are most in need of retirement planning most at risk. ${ }^{6}$

Although financial illiteracy is a widespread problem, the evolution of workplace retirement investing exacerbates the problem by imposing responsibility for financial well-being in retirement on a group of people who are particularly ill-suited for the task. We term these people "workplace-only investors," which we define as people whose only exposure to investment decisions is by virtue of their participation in an employersponsored $401(\mathrm{k})$ plan or the equivalent. We view workplaceonly investors as forced or involuntary investors in that their participation in the financial markets is a product of their employment and unlikely the result of informed choice.

This Article presents the first research that focuses specifically on the financial literacy of workplace-only investors. As we document, data from the National Financial Capability Study (NFCS) demonstrates that workplace-only investors suffer from higher levels of financial illiteracy than other investors. These involuntary investors are particularly vulnerable to poor financial choices, choices that they would likely avoid but for the obligations imposed on them by the structure of their retirement plans. This lack of financial literacy is critical. Al-

3 See, e.g., Annamaria Lusardi \& Olivia S. Mitchell, The Economic Importance of Financial Literacy: Theory and Evidence, 52 J. ECON. LiT. 5, 24-26 (2014) (discussing how "[retirees] must forecast their (and their partner's) survival probabilities, investment returns, pension income, and medical and other expenditures.").

4 See id. at 6, 34 (defining financial literacy as "peoples' ability to process economic information and make informed decisions about financial planning, wealth accumulation, debt, and pensions" and concluding that "low levels of financial knowledge are pervasive.").

5 See, e.g., Jill E. Fisch, Tess Wilkinson-Ryan \& Kristin Firth, The Knowledge Gap in Workplace Retirement Investing and the Role of Professional Advisors, 66 DUKE L.J. 633, 671 (2016) (finding that "financial literacy is a strong predictor of investment outcomes").

6 Annamaria Lusardi \& Olivia S. Mitchell, Financial Literacy and Retirement Planning in the United States, 10 J. PENSION ECON. \& Fin. 509, 518 (2011). 
though the typical $401(\mathrm{k})$ plan requires workplace-only investors to take primary responsibility in making investment decisions for their own retirement, as we show, they lack the knowledge necessary to do so appropriately.

This is not to criticize the shift from defined benefit plans to defined contribution plans. As we detail below, defined benefit plans suffered from a variety of problems, the most acute of which were chronic underfunding 7 and the fact that participants in defined benefit plans risked losing their benefits if they changed employers. ${ }^{8}$ Defined benefit plans are a big impediment to labor mobility, because many workers change jobs frequently. Defined contribution plans mitigate these problems. They do so, however, by imposing primary responsibility on plan participants for making critical decisions about retirement investing, without adequately addressing the limited ability of participants to do so.

The problem of financial illiteracy of plan participants is compounded by the fact that the existing regulatory treatment of defined contribution plans uses the construct of participant choice as a basis for imposing limited responsibility on employers for the financial well-being of their employees in connection with retirement investing. 9 So long as an employer-sponsored defined contribution plan delegates investment responsibility to plan participants in accordance with Department of Labor (DOL) regulations and meets certain minimal criteria, the employer is relieved of fiduciary responsibility for investment losses suffered by its employees. ${ }^{10}$

Concededly, participant choice does not shield an employer from all potential liability. Employers have consistently faced litigation challenges for failure to offer their employees an appropriate retirement plan, ${ }^{11}$ and, even in the absence of litigation, many employers have sought to review and refine their retirement plans. ${ }^{12}$ Critically, however, the law does not impose any obligation on employers to ensure that their employees have sufficient financial literacy to navigate the decisions

7 See infra note 25 and accompanying text.

8 See infra notes 21-22 and accompanying text.

9 See, e.g., Renfro v. Unisys Corp., 671 F.3d 314, 327 (3d Cir. 2011) (“An ERISA defined contribution plan is designed to offer participants meaningful choices ....").

10 See 29 U.S.C. § 1104(c)(1)(A) (2012) (providing that plan fiduciaries are not responsible for losses which result from participants' exercise of control).

11 See, e.g., Dana M. Muir, Revenue Sharing in 401(k) Plans: Employers as Monitors?, 20 CONN. INS. L.J. 485, 504-05 (2014) (describing typical litigation).

12 See id. at 505-06. 
associated with retirement investing appropriately or to safeguard them from poor financial decisions resulting from financial illiteracy. Our findings suggest that such obligations are long overdue.

Congress is continuing to try to make self-directed retirement savings more effective. For example, the Retirement Enhancement and Savings Act (RESA) was originally introduced into Congress in 2018 and was reintroduced in February 2019 before the Ways and Means Committee. ${ }^{13}$ The proposals in RESA continue to rely on participant choice, however, which, as we detail below, are of limited utility unless participants can choose knowledgeably.

The Article proceeds as follows. In Part I, the Article briefly traces the progression from defined benefit plans to defined contribution plans and explains the manner in which this progression has changed the role of the plan participant. Part II describes the legal standards applicable to an employer in connection with their 401(k) plan. In Part III, the Article reports our findings that people who invest exclusively through an employer-sponsored $401(\mathrm{k})$ plan are less financially literate than other investors and their personal finances are also quite different than other investors. Part IV considers the implications of this finding for the viability of participant-directed retirement savings. In Part V, we identify two potential responses. One possibility is that ERISA could be modified to impose greater responsibility on plan sponsors. We identify limitations in the viability of this option, as well as the risk that it would decrease employer willingness to provide retirement plans for their workers. Alternatively, employer-sponsors of participant-directed $401(\mathrm{k})$ plans could be required to evaluate and remediate the financial literacy of plan participants, thereby enhancing the effectiveness of participant choice. After discussing both, we suggest that the second alternative is the more promising and offer preliminary reflections on how employers could do so effectively.

13 Retirement Enhancement and Savings Act of 2018, H.R. 5282, 115th Cong. (2018), https://www.congress.gov/bill/115th-congress/house-bill/5282/ text\#toc-H1077D5B691CE4439BF378EADF2E8581B [https://perma.cc/C7QSMRGJ]. 


\section{The Evolution of Defined Contribution Plans}

For decades, workers relied on employer-provided pension plans for financial support in retirement. ${ }^{14}$ Employer-sponsored retirement savings plans began with the classic pension plan, also known as a defined benefit plan, and the state and local governments provided the first such plans to public sector workers in the mid-1800s. ${ }^{15}$ In 1875, the American Express Company created the first private sector pension plan in the United States. ${ }^{16}$ Over the next fifty years, the popularity of private pension plans increased, and by 1925 more than 400 plans existed in the United States, covering more than four million workers. ${ }^{17}$ Following the Great Depression, private pension plans continued to increase, fueled by tax incentives, the strong demand for labor following World War II, and union negotiations. ${ }^{18}$ Pension coverage increased to over $40 \%$ in the 1940 s and ' 50 s, and pension assets increased from $\$ 2.4$ billion to $\$ 57$ billion in twenty years. ${ }^{19}$

These early public and private sector pension plans were defined benefit plans meaning that they paid a retired employee a fixed monthly amount after retirement. The employee's benefit (the defined benefit) was typically calculated based on the employee's salary when he or she retired and the length of service. ${ }^{20}$ In part, the structure of the pension plan was designed to facilitate employee retention through a payout structure that encouraged workers to stay with the same employer until retirement. ${ }^{21}$ This meant that, in many cases, defined benefit plans were not portable and, as a result, workers often forfeited benefits when they changed jobs. Because job

14 See Liz Davidson, The History of Retirement Benefits, WORKFORCE (June 21, 2016), https://www.workforce.com/2016/06/21/the-history-of-retirement-bene fits / [https://perma.cc/S3CS-N3E4].

15 Id. See also Robert L. Clark, LeE A. Craig \& JaCk W. Wilson, A History of Public Sector Pensions In the United States 37 (2003).

16 Davidson, supra note 14; JUSTIN OWENS \& JOSHUA BARBASH, RUSSELL INVESTMENTS RESEARCH, DEFINED BENEFIT PLANS: A BRIEF HISTORY 2 (2014), https://russell investments.com/-/media/files/us/insights/institutions/defined-benefit/de fined-benefit-plans-a-brief-history.pdf?la=en [https://perma.cc/62ES-GXHR].

17 OWENS \& BARBASH, supra note 16.

18 Id. at 3.

19 Id.

20 See Martin Gelter, The Pension System and the Rise of Shareholder Primacy, 43 SETON Hall L. ReV. 909, 922 (2013).

21 Id. 
mobility was increasing, lack of portability was a growing problem. ${ }^{22}$

In a defined benefit plan, "[t]he employer is responsible for funding the benefit, investing and managing plan assets, and bearing the investment risk." 23 To fund defined benefit plans, employers typically pay money into their plans every year. The plan invests that money in a variety of assets such as stocks and bonds. ${ }^{24}$ The expectation is that the plan's assets would grow and be sufficient to meet the plan's obligations. This expectation was often not met, for a variety of reasons. Many plans were underfunded. ${ }^{25}$ Others invested in overly risky assets-it was common for plans to be funded largely in the employer's stock. ${ }^{26}$ Employers also faced increasing liability due to their employees' increasing longevity. ${ }^{27}$ And, as one commentator notes "embezzlement of plan assets was not uncommon." 28 Defined benefit plans were also criticized for the size of the benefits that they paid out. In an era of economic growth,

22 See Alexandra Lopez-Pacheco, How We Got Here: The Gradual Rise of the Defined Contribution Pension, FIN. PosT (Dec. 6, 2012, 7:52 PM), http://business. financialpost.com/executive/how-we-got-here-the-gradual-rise-of-the-definedcontribution-pension [https://perma.cc/2R7G-BWC5] (describing the lack of portability of defined benefit plans).

23 U.S. Gov't Accountability OfFice, GAO-04-176T, PRIVATE Pensions: ChangING Funding RULES AND ENHANCING INCENTIVES CAN IMPROve PLAN Funding $1 \mathrm{n} .1$ (2003), http://www.gao.gov/new.items/d04176t.pdf. [https://perma.cc/93JEANQC].

24 See, e.g., Elizabeth F. Brown, Lessons from Efforts to Manage the Shift of Pensions to Defined Contribution Plans in the United States, Australia, and the United Kingdom, 53 AM. Bus. L.J. 315, 317 (2016) ("Normally, defined benefit pension plans invest in a variety of assets, although a large percentage of them are invested in financial products such as stocks, bonds, commodities, and derivatives.").

25 See Lopez-Pacheco, supra note 22 (explaining that many defined benefit plans became underfunded as interest rates dropped); see also U.S. Gov'T ACCOUNTABILITY OFFICE, supra note 23, at 1 (describing pension underfunding as "a crucial issue threatening the retirement security of millions of America's workers and retirees").

26 The trend to fund employee retirement with the employer's stock continued after the shift to defined contribution plans. See, e.g., Gelter, supra note 20, at 928 (noting that "before the market downturn in 2001, in a number of large firms-including Proctor \& Gamble, Coca-Cola, and General Electric-more than $75 \%$ of $401(\mathrm{k})$ plan assets consisted of company stock."). Gelter also notes that "firms may have good reasons to encourage employees to invest their retirement assets with them." Id.

27 See Brown, supra note 24, at 317 (explaining that employers under a defined benefit plan face the risk that employees may live longer than expected, so that the pension plan funds may not be sufficient to cover the pension obligations).

28 OWENS \& BARBASH, supra note 16, at 3. 
some commentators questioned whether workers were receiving as much as they should receive. ${ }^{29}$

Congress enacted the Employee Retirement Income Security Act (ERISA) in 1974 to respond, in part, to the concerns about employer-provided pension plans. ${ }^{30}$ ERISA focused on improving the security of employees' pension benefits. Perhaps the most significant component of ERISA, at least in the short term, was its minimum funding requirement for defined benefit plans. ${ }^{31}$ ERISA also imposed fiduciary obligations on employer and others involved in managing a pension plan. ${ }^{32}$ In addition, ERISA imposed various rules on the structure of pension plans, including vesting and participation requirements. ${ }^{33}$

The adoption of ERISA created the greatest regulatory burden for employers that provided a defined benefit plans because, under ERISA, the plan's fiduciaries were "responsible for investing the assets of the plan to ensure that there will be enough money to meet future obligations to plan participants." 34 This meant that, if an employer underfunded its plan or made poor investment decisions so that the plan did not have enough assets to pay the required benefits, the employer was responsible for the shortfall. One way for employers to avoid their pension liability was by declaring bankruptcy, and mounting pension obligations led a number of major employers to do so. ${ }^{35}$

Employers can reduce their liability exposure by shifting to defined contribution plans. ${ }^{36}$ In a defined contribution plan, individual employees contribute a portion of their wages, deter-

29 See Lopez-Pacheco, supra note 22 (reporting concern during "days of high interest rates" that defined benefit plans were causing employees to miss out on high returns).

30 Employee Retirement Income Security Act of 1974, Pub. L. No. 93-406, 88 Stat. 829 (1974) (codified as amended at 29 U.S.C. $§ \S 1001-1461$ and in scattered sections of the Internal Revenue Code, 26 U.S.C.).

31 See Gelter, supra note 20, at 929 ("DB plans were subjected to minimum funding rules, given that DB plans had previously often been woefully underfunded.").

3229 U.S.C. § 1104(a) (2018).

3329 U.S.C. §§ 1052-53.

34 James Kwak, Improving Retirement Savings Options for Employees, 15 U. PA. J. Bus. L. 483, 507 (2013).

35 See id. at 520 (explaining that employer-sponsored pension plan's bankruptcy would shift pension obligations to taxpayers); see, e.g., Jonathan Barry Forman \& Michael J. Sabin, Tontine Pensions, 163 U. PA. L. REV. 755, 802 n.174 (2015) (noting that City of Detroit went bankrupt largely due to pension debts).

36 See, e.g., Anne Tucker, Retirement Revolution: Unmitigated Risks in the Defined Contribution Society, 51 Hous. L. REV. 153, 167 (2013) (explaining that "[r]egulatory burdens on defined benefit plans unintentionally created incentives for employer sponsors to shift from defined benefit plans to defined contribution 
mined in advance, to the retirement plan. ${ }^{37}$ Each employee's individual contributions go to an individual account and are invested, and the return on these contributions determines the amount of money available to the employee upon retirement. In some cases, the employer matches all or a portion of the employee's contribution. ${ }^{38}$ Because the contributions are segregated from the outset, unlike in a defined benefit plan, the security of the employee's retirement savings is not jeopardized by the employer's financial condition.

Although employers can, in theory, manage the investment of their employees' contributions in a defined contribution plan, as a matter of practice, they do not do so. ${ }^{39}$ Instead, employers offer their employees a menu of investment choices, and individual plan participants designate how their money is to be invested from among those choices. Because the employees, not the employer, decide both how much to invest and how to invest their contributions, these plans are described as selfor participant-directed. ${ }^{40}$ Participant-directed plans substantially reduce the employer's liability exposure because, so long as the employer complies with the requirements of section 404(c) of ERISA, the statute provides a safe harbor or liability shield from losses suffered by plan participants, ${ }^{41}$ even in situations in which the employer has arguably breached its duties. ${ }^{42}$ The three requirements for the safe harbor are (1) that the plan offer participant control; (2) that the participant actually exercise control and (3) that the losses result from the participant's exercise of control. ${ }^{43}$

plans to avoid the additional costs and liabilities associated with pension funding responsibilities").

37 See Edward A. Zelinksy, The Defined Contribution Paradigm, 114 YALE L.J. 451,457 (2004) (explaining that defined contribution plans work like individual accounts in which the employees' benefits are determined by their contributions and investment decisions).

38 See, e.g., Ryan Bubb, Patrick Corrigan \& Patrick L. Warren, A Behavioral Contract Theory Perspective on Retirement Savings, 47 ConN. L. REV. 1317, 1346 (2015) (exploring employer incentives with respect to matching employee plan contributions).

39 See, e.g., Forman \& Sabin, supra note 35, at 806 (explaining that, although employers could, in theory, manage their employees' investments in a defined contribution plan, "we know of no defined contribution plans like that").

40 See, e.g., Zelinksy, supra note 37, at 457 (calling defined contribution assets "self-directed" because the employee has control over the investments).

41 ERISA § 404; 29 U.S.C. § 1104(c) (2012) (stipulating that neither the participant nor anyone else is a fiduciary for a retirement account over which the participant exercises control).

42 DiFelice v. U.S. Airways, Inc., 397 F. Supp. 2d 758, 775 (E.D. Va. 2005).

43 See Tucker, supra note 36, at 204 (describing the requirements of section 404(c)). 
The ERISA safe harbor does not provide employers with a complete liability shield. Employers may be liable for providing a plan that is structured inappropriately, such as one with an insufficient range of investment options, ${ }^{44}$ unsuitable investment options, or that charges excessive fees. However, courts have granted plan fiduciaries significant discretion with respect to their choices about plan structure and investment options. ${ }^{45}$ Litigation asserting these claims is relatively common and will be discussed in more detail below. Despite this litigation, an employer faces far more limited liability exposure in connection with a defined contribution plan. In addition to reduced liability exposure, defined contribution plans are less costly for employers and are subject to less burdensome regulatory requirements. ${ }^{46}$

These factors have led most employers to shift from offering defined benefit plans to defined contribution plans and, in some cases, to convert existing defined benefit plans to defined contribution plans. ${ }^{47}$ From 1983 to 1993 , the number of defined contribution plans increased more than fivefold. ${ }^{48}$ Today most private employers and even many public employers have shifted to the defined contribution plan. ${ }^{49}$

44 See 29 C.F.R. § 2550.404c-1(b)(3)(ii)(C) (2015) (requiring a minimum of three investment options for retirement plans).

45 See Tucker, supra note 36, at 205-06.

46 See, e.g., Regina T. Jefferson, Rethinking the Risk of Defined Contribution Plans, 4 FLA. TAX REV. 607, 614-15 (2000) (describing defined benefit plans as subject to "more onerous regulations" and greater costs and administrative burdens).

47 Tucker, supra note 36, at 205 (observing that the "safe harbor and discretionary deference create incentives for employer sponsors to (1) provide or convert existing pension benefits into a self-directed defined contribution model").

48 Leora Friedberg \& Michael T. Owyang, Not Your Father's Pension Plan: The Rise of 401(k) and Other Defined Contribution Plans, 84 FED. RES. BANK ST. LOUIS REV. 22, 23 (Jan./Feb. 2002), https://files.stlouisfed.org/files/htdocs/publica tions/review/02/01/23-34Friedberg.pdf [https://perma.cc/E9H4-579G].

49 See, e.g., NEWPORT GROUP, COMPENSATION, RETIREMENT, AND BENEFITS TRENDS REPORT 12 (2017/2018 ed.), https://www.newportgroup.com/newportgroup/me dia/documents/c202b-112717-2017-2018-edition-compensation-retirementand-benefits-trends-executive-summary-(002)_1.pdf [https://perma.cc/D7H3VSU6] (reporting results of 2017-2018 in which 91\% of private employers reported offering a defined contribution plan while only $11 \%$ reported offering a defined benefit plan, either alone or in combination with a defined contribution plan); Jerry Geisel, Fortune 500 Continues to Shed Pension Plans, Bus. Ins. (Feb. 22, 2016), https://www.businessinsurance.com/article/20160222/NEWS03/ 160229986 [https://perma.cc/G6DZ-YYFV] (documenting decline in percentage of Fortune 500 companies offering defined benefit plans from $58 \%$ in 1998 to less than $20 \%$ in 2015). Although a majority of public sector employees still participate in defined benefit plans, most of those plans are not open to new employees. U.S. Bureau of Labor Statistics, Three Quarters of State and Local Government Workers Were in Defined Benefit Pension Plans In 2016 (May 3, 2017), https:// 
Significantly, the shift to defined contribution plans reduced the number of employees who participated in employerbased retirement plans because it allowed individual employees to choose not to participate. ${ }^{50}$ In response to this concern as well as literature suggesting that enrollments would be higher under a system in which employees were automatically enrolled in their employer's plan and then had to take action to opt out, if they chose, ${ }^{51}$ Congress adopted the Pension Protection Act (PPA) of 2006.52 The PPA made automatic enrollment in defined contribution plans easier and clarified the employer's obligations with respect to auto-enrollment. ${ }^{53}$ In particular, the PPA authorized employers that adopted autoenrollment to invest employees' contributions in a qualified default investment alternative, which was defined by the statute as either (1) "diversified so as to minimize the risk of large losses" and "designed to provide . . . a mix of equity and fixed income exposures based on the participant's age, target retirement date (such as normal retirement age under the plan) or life expectancy," or (2) "consistent with a target level of risk appropriate for participants of the plan as a whole." 54 Traditional target date funds and balanced funds are commonly used as default options. ${ }^{55}$

The response to the PPA was significant-as of 2012, approximately $40 \%$ of Fortune 100 companies in the United States had implemented auto-enrollment, and participation

www.bls.gov/opub/ted/2017/three-quarters-of-state-and-local-governmentworkers-were-in-defined-benefit-pension-plans-in-2016.htm [https://perma.cc/ EX8H-556B].

50 See, e.g., Paul M. Secunda, The Behavioral Economic Case for Paternalistic Workplace Retirement Plans, 91 IND. L.J. 505, 516 (2016) (describing a "massive retirement crisis" caused by defined contribution plans and identifying failure of workers to participate in such plans as one contributing factor).

51 See, e.g., Dana M. Muir, Choice Architecture and the Locus of Fiduciary Obligation in Defined Contribution Plans, 99 IowA L. REV. 1, 12-13 (2013) (explaining that whether the plan default is participation or non-participation "dramatically affects participation rates").

52 Pension Protection Act of 2006, Pub. L. No. 109-280, §§ 821-33, 901-06, 120 Stat. 780, 782-83 (2006); see Jacob Hale Russell, The Separation of Intelligence and Control: Retirement Savings and the Limits of Soft Paternalism, 6 WM. \& MARY BUS. L. REV. 35, 51 (2015) ("The PPA's strategy was inspired by academic studies that showed huge increases in enrollment when companies switched to auto-enrolling employees, who could then choose to opt out, in 401(k) plans." (footnote omitted)).

53 Auto-enrollment had previously been permissible, and IRS revenue rulings in 1998 and 2000 facilitated its use. See Brown, supra note 24, at 330.

5429 C.F.R. § 2550.404c-5 (2009).

55 Ian Ayres \& Quinn Curtis, Beyond Diversification: The Pervasive Problem of Excessive Fees and "Dominated Funds" in 401(k) Plans, 124 YALE L.J. 1476, 1516 (2015). 
rates rose at employers that shifted to auto-enrollment. ${ }^{56}$ According to a 2018 Willis Towers Watson survey, the percentage of employers using auto-enrollment has grown to $73 \% .{ }^{57}$ One study found that participation rates among new hires more than doubled under automatic enrollment versus voluntary enrollment. 58

The overall effectiveness of auto-enrollment may have been overstated. While automatic enrollment has clearly increased enrollment into retirement accounts, it is much less clear if it has increased net savings or employee's wellbeing. Recent census data suggests that employee participation rates may be much lower than previously thought, particularly at smaller employers. ${ }^{59}$ Research has identified the fact that the employer-selected default rate is "sticky," meaning that most employees do not deviate from the savings rate set by their employer, which has been normally quite low. ${ }^{60}$ This can lead to low overall savings levels. ${ }^{61}$ These rates are particularly problematic to the extent that plan participants view the employer-selected rate as a benchmark and assume that saving at that rate will be sufficient to meet their retirement needs. ${ }^{62}$

56 Susan Farris et al., Defined Contribution Plans of Fortune 100 Companies for the 2012 Plan Year, TOWERS WATSON: INSIDER (Feb. 24, 2014), https:// www.towerswatson.com/en-US/Insights/Newsletters/Americas/insider/2014/ defined-contribution-plans-of-fortune-100-companies-in-2012 [https:// perma.cc/Y5NF-H2JZ].

57 Paula Aven Gladych, Employers Adding 401(k) Auto-Enrollment in Record Numbers, EMP. BENEFIT NEwS (Feb. 27, 2018), https://www.benefitnews.com/ news/employers-adding-401-k-auto-enrollment-in-record-numbers?regconf $=1$ [https://perma.cc/U2UQ-K9U8].

58 Jeffrey W. Clark, Stephen P. Utkus \& Jean A. Young, Automatic Enrollment: The Power of the Default, VANGUARD 1, 4 (2015), https://pressroom.vanguard. com/nonindexed/Automatic_enrollment_power_of_default_1.15.2015.pdf [https://perma.cc/V975-9N3L].

59 See, e.g., Dan Kadlec, A Popular Cure for the Retirement Crisis Isn't Making Much Headway, Money (Mar. 9, 2017), http://time.com/money/4693386/401kauto-enrollment-retirement-saving/ [https://perma.cc/9BFP-D4JX] (reporting that "[s]ome $79 \%$ of Americans are eligible to contribute to a $401(\mathrm{k})$ but only $41 \%$ of eligible workers do so").

60 Ryan Bubb \& Richard H. Pildes, How Behavioral Economics Trims Its Sails and Why, 127 HARV. L. REV. 1593, 1618 (2014).

61 See Kelley Holland, The Downside of Automatic 401(k) Enrollment, CNBC (June 29, 2015), https://www.cnbc.com/2015/06/29/the-downside-of-automatic-401k-enrollment.html [https://perma.cc/UM2E-PWJB] (reporting that automatic enrollment increased employee participation but reduced contribution levels).

62 See, e.g., Susan J. Stabile, The Behavior of Defined Contribution Plan Participants, 77 N.Y.U. L. REV. 71, 81-82 (2002) (explaining that more than half of employees automatically enrolled may never adjust the default contribution rate). Participants may also take cues from the structure of their employer's match formula in determining what an appropriate savings level is. See also Stephen 
Another problem is that, if employer-selected rates are too high and/or employees' precautionary savings are minimal, employees may offset the savings by increasing their levels of debt. One recent paper studied the shift by the U.S. Army to automatic enrollment in its Thrift Savings Plan (TSP) and found evidence of this effect. The research showed that "a significant portion of the increase in TSP contributions induced by automatic enrollment is offset by increased debt outside the TSP."63 This effect is not surprising given the evidence about household debt, the prevalence of debt in many household balance sheets, and the paucity of precautionary savings. ${ }^{64}$ The recent government shutdown provided acute evidence about the lack of emergency savings among those with government jobs, which normally carry good pension benefits. 65

More generally, one size does not fit all. Both the employer's selection of a savings rate and a choice of investment for the employees' savings raise potential problems because employees vary in their age, outside savings, income, debt obligations, and funding needs when they retire. There is no way that an employer can designate a default rate or investment option that is right for everyone. But employees typically lack any basis by which to evaluate whether the employer's default choices are appropriate for them and stick to what is chosen for them.

The most recent adaption to the problem of savings rates that are too low is auto-escalation. Recognizing that the initial

Miller, Auto Escalation Beats Inertia, So Why the Hesitancy?, SOC'Y FOR HUMAN RES. MGMT. (Feb. 8, 2016), https://www.shrm.org/resourcesandtools/hr-topics/bene fits/pages/auto-escalation-hesitancy.aspx [https://perma.cc/UP32-WVYJ]. The concern may be exacerbated by the extent to which employers focus on participation rates rather than evaluating whether their employees are saving enough for retirement. See, e.g., Gladych, supra note 57 (reporting that while $88 \%$ of plans sponsors measure participation rates, only $35 \%$ measure the retirement readiness of their participants).

63 John Beshears et al., Borrowing to Save? Unintended Consequences of Automatic Enrollment 1, 11 (Feb. 10, 2017) (unpublished manuscript), https:// scholar.harvard.edu/files/laibson/files/total_savings_impact_2017_12_06.pdf [https://perma.cc/89ZT-NUSC].

64 See Emmie Martin, The Government Shutdown Highlights How Few Americans Have Enough Money Saved for Emergencies, CNBC MAKE IT (Jan. 16, 2019, 8:45 AM), https://www.cnbc.com/2019/01/15/government-shutdown-highlights-how-few-americans-have-emergency-savings.html [https://perma.cc/ X53K-8B5G] (discussing the widespread lack of emergency savings in American households); infra Table 4a (detailing the prevalence of debt in American households).

65 See, e.g., Martin, supra note 64 (reporting that the 2019 government shutdown forced some federal workers to "rely on credit cards" or donations due to a temporary loss of income). 
default savings rates common to auto-enrollment may be too low, some employers are adopting plans in which the participants' default contribution increases automatically. ${ }^{66}$ A number of commentators have cited the benefits of auto-escalation, but employers have been somewhat hesitant to adopt this feature. ${ }^{67}$ Yet again, this feature fails to take into account that workers may have different needs and that they change employers often.

Use of auto-enrollment and other features to increase employee retirement savings beyond the initial enrollment decision has become more popular as prominent employers have taken the lead. ${ }^{68}$ For example, in 2017, American Express announced that it had adopted an auto-enrollment plan with auto-escalation for all new employees. American Express also communicates at least once annually with all its employees who are not enrolled in the plan or who invest less than the full amount that is matched by the company. ${ }^{69}$ As we discuss in more detail below, automatic enrollment and automatic escalation may work well in an environment in which employees stay with a single firm for a long time, but this feature is not common anymore in the workplace and was a factor contributing to the shift toward defined contribution pension plans.

II

\section{FIDUCIARY LIABILITY FOR 401(K) PLANS}

ERISA is premised on a fiduciary framework. Employers and plan administrators are subject to various fiduciary obligations, including a duty to select and monitor the plan's investment options ${ }^{70}$ and a duty to refrain from conflicts of interest and self-dealing in connection with the administration of the plan. ${ }^{71}$ As noted above, so long as participants exercise mean-

66 See Marlene Y. Satter, Auto-Enroll, Escalation Features on Rise in 401(k)s as Employers Add Enhancements, BENEFITSPRO (Feb. 27, 2018, 11:39 AM), https://www.benefitspro.com/2018/02/27/auto-enroll-escalation-features-onrise-in-401ks-a/ [https://perma.cc/KAB8-8PCC].

67 See e.g., Miller, supra note 62 (arguing that auto-escalation has substantial benefits despite employer hesitancy).

68 See Robert Steyer, American Express Starts Auto Enrollment in 401(k) for New Employees, PEnsions \& INV. (July 13, 2017, 1:00 AM), http://www.pionline. com/article/20170713/ONLINE/170719886/american-express-starts-auto-enrollment-in-401k-for-new-employees [https://perma.cc/9YLM-Q8M3] (reporting that American Express adopted auto-enrollment and auto-escalation features); Satter, supra note 66 (reporting that $60 \%$ of employee retirement plans now offer an auto-escalation feature).

69 Steyer, supra note 68.

70 Tibble v. Edison Int'l, 135 S. Ct. 1823, 1829 (2015).

7129 U.S.C. § 1106(b) (2018). 
ingful control over their investments, the ERISA safe harbor protects plan fiduciaries from losses suffered by the participants. ${ }^{72}$

Despite this safe harbor, plan participants have brought a number of litigation challenges in connection with employersponsored $401(\mathrm{k})$ plans. ${ }^{73}$ These cases alleged that employers and plan administrators breached their fiduciary duties by providing menus of investment options that offered an insufficient number of choices of investment options, inferior investment options, or investment options that charged high fees. Courts evaluating these challenges have given considerable weight to the role of participant choice, adopting the view that, as a general matter, imperfections in some of the investment options can be mitigated so long as the plan contains some high-quality options and participants have sufficient choice.

In the leading case, Hecker $v$. Deere \& Co., ${ }^{74}$ the Seventh Circuit held that a fiduciary satisfies its obligations under ERISA by offering plan participants a suitable number of investment options with fees that were subject to market competition. Deere's plan provided employees with "a generous choice of investment options" that included " 23 different Fidelity mutual funds, two investment funds managed by Fidelity Trust, a fund devoted to Deere's stock, and a Fidelity-operated facility called Brokerage Link, which gave participants access to some 2,500 additional funds managed by different companies."75 Quoting the district court with approval, the Seventh Circuit noted that the fees among the primary funds ranged from "just over $1 \%$ to as low as .07\%"76 and were offered to the general public, so the fees "were set against the backdrop of market competition."77 Accordingly, the court concluded that the plan participants had the ability to protect themselves through their choice among these options, qualifying the plan for the protection of the statutory safe harbor. ${ }^{78}$

$72 \quad 29$ U.S.C. § $1104(\mathrm{c})(1)$.

73 See generally Mercer Bullard, The Social Costs of Choice, Free Market Ideology and the Empirical Consequences of the 401(k) Plan Large Menu Defense, 20 CONN. INS. L.J. 335, 340-50 (2014) (describing several types of litigation challenges to employer-sponsored 401(k) plans).

74556 F.3d 575 (7th Cir. 2009).

75 Id. at 578 .

76 Id. at 581 .

77 Id. at 586; see also Hecker v. Deere \& Co., 496 F. Supp. 2d 967, 976 (W.D. Wis. 2007) (concluding that it was "untenable to suggest that all of the more than 2500 publicly available investment options had excessive expense ratios").

78 See Hecker, 556 F.3d at 589. Notably, the Eighth Circuit reached a different result but employed similar reasoning in Braden v. Wal-Mart Stores, Inc., 588 
Similarly, in Renfro $v$. Unisys, the Third Circuit, in evaluating allegations of excessive fees, highlighted the fact that "[a]n ERISA defined contribution plan is designed to offer participants meaningful choices about how to invest their retirement savings." 79 The court found that the Unisys plan, which contained "seventy-three distinct investment options [including] funds with a variety of risk and fee profiles, including low-risk and low-fee options" offered a reasonable range of investment options and that, as a result, plaintiffs had not "plausibly alleged a breach of fiduciary duty." 80

Perhaps the most important in these series of cases is the Supreme Court's decision in Tibble $v$. Edison International, ${ }^{81}$ in which the Court held that ERISA fiduciaries have a continuing duty to monitor the quality of the investments offered in their $401(\mathrm{k})$ plans. The Court specifically noted that this duty includes an obligation to remove imprudent investment options from the plan. The Court did not consider, however, what constituted an imprudent investment option or the extent to which a fiduciary could be liable if the plan offered sufficient alternatives.

Recently a series of high-profile lawsuits targeted twelve major universities with similar allegations, challenging the structure of their 403(b) plans (the nonprofit equivalent of $401(\mathrm{k})$ plans) including the choice of investment options, imprudent monitoring, and excessive fees. ${ }^{82}$ The lawsuits responded, in part, to the Tibble decision by alleging a breach of fiduciary duty due to the plan sponsors' failure to remove underperforming funds from the plan. In addition, and, in contrast to some of the earlier challenges, most of these lawsuits also alleged that the plans were improperly structured because

F.3d 585, 596 (8th Cir. 2009). The Braden court refused to dismiss a lawsuit claiming that Wal-Mart's $401(\mathrm{k})$ plan included funds with unreasonably high fees, reasoning in part that the Wal-Mart plan offered a limited number of options, consisting of "ten mutual funds, a common/collective trust, Wal-Mart common stock, and a stable value fund." Id. at 589. Comparing the plan to the one at issue in Deere, the court observed that the "far narrower range of investment options available in this case makes more plausible the claim that this Plan was imprudently managed." Id. at 596 n.6.

79 Renfro v. Unisys Corp., 671 F.3d 314, 327 (3d Cir. 2011).

80 Id. at 327-28.

81 Tibble v. Edison Int'l, 135 S. Ct. 1823, 1828 (2015).

82 See Clarissa A. Kang, New Wave of Retirement Fee Litigation: The University 403(b) Lawsuits, TRUCKER HUSs (Jan. 2017), http://www.truckerhuss.com/2017/ 02/new-wave-of-retirement-fee-litigation-the-university-403b-lawsuits / [https:/ /perma.cc/E3QV-XPJN]; see also Nicolas v. Trs. of Princeton Univ., 2017 U.S. Dist. LEXIS 209100, at *7 (D.N.J. Dec. 19, 2017) (citing several such cases). 
they offered plan participants too many investment options. ${ }^{83}$ The complaints alleged that too many options "confus[ed]" participants and prevented them from making educated choices. ${ }^{84}$

Many of the cases are still pending, and courts have shown varied degrees of sympathy to the plaintiffs' claims. ${ }^{85}$ For the most part, however, the courts have continued to focus on the primacy of participant choice and to dismiss claims that asked the court to second-guess the sponsor's choice of investment options. As the court explained in Henderson v. Emory University, for example, "[h]aving too many options does not hurt the Plans' participants, but instead provides them opportunities to choose the investments that they prefer." 86

Similarly, the court's decision dismissing the lawsuit against the University of Pennsylvania highlighted the primacy of participant choice over an evaluation of each individual investment option. The court reasoned that the liability standard under ERISA required the plaintiffs to show "systemic mismanagement such that individuals are presented with a Hobson's choice between a poorly-performing $\S 401(\mathrm{k})$ portfolio or no $\$ 401(\mathrm{k})$ at all." 87 The court described viable potential claims for a plan participant under ERISA as follows:

A plaintiff can allege an inadequate "mix and range of options" by alleging insufficient choice, that all (or the vast majority of) options breach the fiduciary duty, an insufficient variety among the range of options, or a kickback scheme where the fiduciaries directly benefit at the expense of plan participants. ${ }^{88}$

III

THE DisTinCtive FinANCIAL ILLITERACY OF WORKPLACEONLY INVESTORS

A critical policy consideration in evaluating employer responsibility with respect to the structure of $401(\mathrm{k})$ plans is the

83 See, e.g., Henderson v. Emory Univ., 252 F. Supp. 3d 1344, 1350 (N.D. Ga. 2017) (citing plaintiff's allegation that "having too many investment options is imprudent").

84 See, e.g., Sacerdote v. N.Y.U., 2017 U.S. Dist. LEXIS 137115, at *35 (S.D.N.Y. Aug. 25, 2017) (noting plaintiffs' claim that the failure to limit the number of investment options is "confusing" for participants).

85 See, e.g., Nicolas, 2017 U.S. Dist. LEXIS 209100, at *7 (observing that in many of the cases, the courts have allowed claims to proceed beyond the motion to dismiss stage).

86 Henderson, 252 F. Supp. 3d at 1350.

87 Sweda v. Univ. of Pa., 2017 U.S. Dist. LEXIS 153958, at*13 (E.D. Pa. Sept. $21,2017)$.

88 Id. at *14. 
ability of plan participants to fend for themselves effectively. Whether employees are able to do so depends, in part, on the financial literacy of this distinctive category of investors-investors that are de facto forced to engage with the financial markets in order to participate in their employer-sponsored retirement plan. To date, however, the literature has not focused on workplace-only investors.

To document the financial knowledge and other characteristics of these investors, we analyze data from the 2015 wave of the NFCS. ${ }^{89}$ This is one of the few surveys that provide detailed information not only on measures of personal finance and indicators of money management behavior but also on the financial literacy of a large and representative sample of the U.S. population. For the purpose of our analysis, we restrict the sample to those aged 25 to 60 and who are not retired, to focus on individuals who are not in school and must save and invest for retirement. 90

Our overall sample consists of 14,640 survey respondents. Of these, approximately $60 \%$ are, in the terminology of this Article, investors, meaning that they invest through an employer-provided retirement account, through a self-directed retirement account, or through nonretirement account investments. Through the questions included in the survey (detailed in the data appendix below), we divide the investors into two groups. The first, whom we term workplace-only investors, are those who have retirement accounts through their employers in which they get to choose how the money is invested but who do not have any other type of retirement account that they have set up themselves ${ }^{91}$ or any other financial investments in stocks, bonds, mutual funds or other securities. Workplace-only investors are not a small group of the population of investors; in fact, they account for $28 \%$ of the population of investors considered in our analysis. Thus, they are an important group to study.

The second group of investors, whom we term active investors, are those who have made decisions about their invest-

89 The NFCS is a project of the FINRA Investor Education Foundation (FINRA Foundation). National Financial Capability Study, FINRA INV. EDUC. Found. (2015), https://www.usfinancialcapability.org/results.php?region=us [https:// perma.cc/2QXM-NGMQ].

90 See the data appendix for a detailed description of the survey and the sample used in this empirical analysis.

91 Other such retirement accounts might include an IRA, Keogh, or SEP IRA. 
ments outside of an employer-provided retirement account. ${ }^{92}$ Specifically, the active investors have private retirement accounts they have set up themselves and/or financial investments in stocks, bonds, mutual funds, or other securities. We aggregate active investors into one group for purposes of comparing them to workplace-only investors, but we also consider them separately because they may display different motives to save and invest. Within the group of active investors, roughly $50 \%$ have both a self-directed retirement account that they set up themselves and other financial investments.

An advantage of using data from the NFCS is that it reports information on levels of financial literacy, and the information is richer than in many other data sets. ${ }^{93}$ Specifically, the NFCS has data on the Big Three financial literacy questions, which measure knowledge of basic financial literacy conceptsnumeracy, inflation, and risk diversification. ${ }^{94}$ The NFCS also reports information on questions that measure knowledge of investing, such as the negative relationship between interest rates and bond prices. ${ }^{95}$ In 2015, a new financial literacy question was added to the NFCS questionnaire measuring the knowledge of the workings of interest compounding in the context of debt. 96

Table 1 reports descriptive statistics about different investment groups by levels of financial literacy and demographics characteristics. ${ }^{97}$

92 The data appendix provides more information about the composition of the investor groups used for this analysis. Active investors can also have a defined contribution account with their employers, which is true for $68 \%$ of active investors in our sample.

932015 National Financial Capability Study State-by-State Instrument (Questionnaire), FINRA INV. EDUC. FOUND. (2015) https://www.usfinancialcapability. org/downloads/NFCS_2015_State_by_State_Qre.pdf [https://perma.cc/2Y58J2C4]. The raw survey data is freely downloadable from Data File Information: 2015 State-by-State Survey, NAT'L Fin. CAPABILITY STUDY (June 19, 2016), https:// www.usfinancialcapability.org/downloads/NFCS_2015_State_by_State_Data_ Excel.zip [https://perma.cc/8NF9-EAZ2].

94 One of us pioneered the development and widespread use of the Big Three financial literacy questions which have been used to measure financial literacy around the world. See Glob. Fin. Literacy Excellence Ctr., Three Questions to MEASURE FINANCIAL LITERACY, http://gflec.org/wp-content/uploads/2015/04/3Questions-Article2.pdf [https://perma.cc/RUF2-7GBJ] (describing the Big Three). For an overview of findings related to the use of the Big Three, see Lusardi \& Mitchell, supra note 6 , at 497.

95 FINRA INV'R EDUC. FOUND., FinANCIAL CAPABILITY IN THE UNITED STATES 2016, at 28 (2016), https://www.usfinancialcapability.org/downloads/NFCS_2015_Re port_Natl_Findings.pdf [https://perma.cc/FTN5-2CG2].

96 Id. at 29.

97 See the data appendix for a description of the variables used in the empirical work. Note that the survey identifies participant characteristics at a specific 
Table 1 shows that workplace-only investors are very different from other investors. Their level of financial literacy is strikingly low and much lower than the financial literacy of active investors. This difference in financial literacy is reflected both by the responses to the Big Three financial literacy questions, which measure basic financial knowledge, and the questions that deal with more sophisticated concepts, such as the concept of compound interest. Specifically, only slightly more than one third (37\%) of workplace-only investors have some basic financial knowledge as measured by the Big Three, and only $35 \%$ can answer the question about compound interest correctly. 
TABLE 1: Descriptive Statistics

\begin{tabular}{|c|c|c|c|c|c|c|}
\hline $\begin{array}{c}\text { Variables } \\
\text { (weighted } \\
\text { mean) }\end{array}$ & $\begin{array}{c}\text { (1) } \\
\text { Active } \\
\text { investor in } \\
\text { financial } \\
\text { markets or } \\
\text { ret. } \\
\text { savings }\end{array}$ & $\begin{array}{c}\text { (2) } \\
\text { Active in } \\
\text { retirement } \\
\text { savings }\end{array}$ & $\begin{array}{c}\text { (3) } \\
\text { Active } \\
\text { investors } \\
\text { in } \\
\text { financial } \\
\text { markets }\end{array}$ & $\begin{array}{c}(4) \\
\text { Workplace- } \\
\text { only } \\
\text { investors }\end{array}$ & $\begin{array}{c}\text { (5) } \\
\text { Investor } \\
\text { population }\end{array}$ & $\begin{array}{c}\text { (6) } \\
\text { General } \\
\text { population }\end{array}$ \\
\hline \multicolumn{7}{|l|}{$\begin{array}{l}\text { Financial } \\
\text { literacy }\end{array}$} \\
\hline $\begin{array}{r}\text { Big Three } \\
\text { correct }\end{array}$ & 0.4728 & 0.4853 & 0.4879 & 0.3658 & 0.4423 & 0.3280 \\
\hline $\begin{array}{r}\text { Risk } \\
\text { diversification }\end{array}$ & 0.6183 & 0.6284 & 0.6359 & 0.4997 & 0.5845 & 0.4669 \\
\hline $\begin{array}{r}\text { Asset/Bond } \\
\text { pricing }\end{array}$ & 0.3873 & 0.4040 & 0.4131 & 0.2612 & 0.3514 & 0.2748 \\
\hline Interest comp. & 0.4401 & 0.4462 & 0.4484 & 0.3510 & 0.4147 & 0.3416 \\
\hline Mortgage & 0.8550 & 0.8663 & 0.8582 & 0.8678 & 0.8586 & 0.7674 \\
\hline Inflation & 0.6780 & 0.6791 & 0.6710 & 0.6339 & 0.6654 & 0.5825 \\
\hline \multicolumn{7}{|l|}{ Gender } \\
\hline Male & 0.5807 & 0.5685 & 0.6134 & 0.5017 & 0.5582 & 0.5072 \\
\hline Female & 0.4193 & 0.4315 & 0.3866 & 0.4983 & 0.4418 & 0.4928 \\
\hline \multicolumn{7}{|l|}{ Ethnicity } \\
\hline White & 0.6559 & 0.6600 & 0.6514 & 0.6647 & 0.6584 & 0.6341 \\
\hline Black & 0.0952 & 0.0891 & 0.0910 & 0.1135 & 0.1004 & 0.1216 \\
\hline Hispanic & 0.1555 & 0.1523 & 0.1577 & 0.1516 & 0.1543 & 0.1661 \\
\hline Asian & 0.0755 & 0.0815 & 0.0822 & 0.0464 & 0.0672 & 0.0552 \\
\hline Other & 0.0179 & 0.0171 & 0.0178 & 0.0239 & 0.0196 & 0.0230 \\
\hline \multicolumn{7}{|l|}{ Age } \\
\hline 25-34 years & 0.2660 & 0.2435 & 0.2787 & 0.2821 & 0.2706 & 0.2915 \\
\hline $35-49$ years & 0.3886 & 0.3924 & 0.3938 & 0.4401 & 0.4032 & 0.3973 \\
\hline 50-60 years & 0.3454 & 0.3641 & 0.3275 & 0.2778 & 0.3262 & 0.3111 \\
\hline \multicolumn{7}{|l|}{ Income } \\
\hline $\begin{array}{r}\text { Below } \\
\$ 25,000\end{array}$ & 0.0670 & 0.0604 & 0.0580 & 0.0573 & 0.0642 & 0.2185 \\
\hline $\begin{array}{r}\$ 25,000- \\
\$ 49,000\end{array}$ & 0.1670 & 0.1569 & 0.1473 & 0.2586 & 0.1931 & 0.2447 \\
\hline $\begin{array}{r}\$ 50,000- \\
\$ 99,000\end{array}$ & 0.4193 & 0.4159 & 0.4170 & 0.4657 & 0.4326 & 0.3415 \\
\hline $\begin{array}{r}\text { Over } \\
\$ 100,000\end{array}$ & 0.3467 & 0.3667 & 0.3778 & 0.2184 & 0.3102 & 0.1953 \\
\hline \multicolumn{7}{|l|}{ Education } \\
\hline $\begin{array}{r}\text { High school or } \\
\text { less }\end{array}$ & 0.1526 & 0.1467 & 0.1425 & 0.2143 & 0.1701 & 0.2628 \\
\hline Some college & 0.3739 & 0.3596 & 0.3643 & 0.4816 & 0.4046 & 0.4265 \\
\hline $\begin{array}{r}\text { College } \\
\text { graduate or } \\
\text { above }\end{array}$ & 0.4735 & 0.4937 & 0.4933 & 0.3041 & 0.4252 & 0.3107 \\
\hline \multicolumn{7}{|l|}{ Marital status } \\
\hline Married & 0.6643 & 0.6797 & 0.6733 & 0.6575 & 0.6624 & 0.5515 \\
\hline $\begin{array}{r}\text { Single, not } \\
\text { married }\end{array}$ & 0.2393 & 0.2263 & 0.2393 & 0.2209 & 0.2340 & 0.3109 \\
\hline $\begin{array}{r}\text { Divorced or } \\
\text { separated }\end{array}$ & 0.0822 & 0.0809 & 0.0729 & 0.1133 & 0.0910 & 0.1213 \\
\hline Widowed & 0.0143 & 0.0130 & 0.0145 & 0.0084 & 0.0126 & 0.0163 \\
\hline
\end{tabular}




\begin{tabular}{rcccccc}
\hline $\begin{array}{r}\text { Employment } \\
\text { Employed } \\
\text { (full, part }\end{array}$ & 0.7615 & 0.7646 & 0.7692 & 0.8119 & 0.7759 & 0.6379 \\
time) & & & & & & \\
Self-employed & 0.1041 & 0.1040 & 0.1101 & 0.0350 & 0.0844 & 0.0863 \\
$\begin{array}{r}\text { Unemployed } \\
\text { Not in the }\end{array}$ & 0.0325 & 0.0323 & 0.0276 & 0.0278 & 0.0312 & 0.0787 \\
labor force & & 0.0991 & 0.0931 & 0.1253 & 0.1086 & 0.1971 \\
\hline Observations & 6,322 & 4,892 & 4,574 & 2,459 & 8,781 & 14,640 \\
\hline \hline
\end{tabular}

Source: 2015 National Financial Capability Study.

Note: Sample restricted to non-retired individuals age 25-60; all estimates are weighted. The averages for the financial literacy variables are lower in column 1 versus column 2 or 3 because there is an overlap of about $50 \%$ between the two investor groups. As expected, the financial literacy of the overlapping group is higher compared to the level of those who belong to one investor group only. The Big Three financial literacy measure is a dummy variable with value 1 if the respondent answered the interest, inflation, and risk diversification questions correctly. The income brackets report household annual income from all sources, such as wages, tips, investment income, public assistance, and retirement plans.

When we further compare across different investor groups, we find that the financial literacy of workplace-only investors differs from the knowledge of those who made active choices in their retirement savings. Even though both types of investors may have similar motives to save and both utilize tax-favored investments, those who set up retirement accounts by themselves display much higher financial literacy than those we define as workplace-only investors. The financial literacy of workplace-only investors is also lower than the financial literacy of those who invested outside of retirement accounts. In other words, those who are likely to have made little or no choice about their retirement account know little about basic financial concepts. These are of course simple correlations, but they highlight the differences in financial knowledge across investors and, in particular, the low levels of financial literacy of workplace-only investors.

The financial literacy of workplace-only investors is particularly low and alarming when looking at concepts specifically connected with investment decisions, such as bond pricing (measuring whether respondents know the inverse relationship between asset pricing and interest rates) and risk diversification (measuring whether respondents know whether a company stock is riskier or safer than a stock mutual fund and what stocks and stock mutual funds are). Only half of workplace-only investors have some rudimentary knowledge of risk diversification and only $26 \%$ know about basic asset pricing. In this respect, the financial knowledge of workplace-only investors more closely resembles that of the general population than the population of investors. 
Table 1 also contains demographic information on our sample population. Looking at the demographic characteristics of the different investor groups, we see that workplace-only investors are more likely to include vulnerable subgroups of the population. For example, workplace-only investors are much more likely than other investors to be people with lower income and less education, those with split families (divorced/ separated), and women. As expected, workplace-only investors are less likely to be self-employed, but self-employment is not the main driver for having a non-employer-based retirement account.

A high proportion of those who have employer-sponsored $401(\mathrm{k})$ accounts are young workers. One may argue that retirement accounts will introduce workers to investment and finance and that their financial literacy will improve over time. At least within our sample, this does not seem to be the case. When we split the sample into two age groups, those younger and those older than age 40, we find that the knowledge gap between workplace-only investors and other investors does not decrease across age groups. Table 2 reports demographic information for the split sample. Table 2 a shows the information for investors under 40 , and Table $2 \mathrm{~b}$ reports the results for investors over 40. Looking at those older than 40, we continue to see a large difference in financial knowledge between workplace-only investors and active investors. Yet again, workplaceonly investors more closely resemble the general older population than the population of older investors. In other words, our older workplace-only investors do not seem to have acquired a lot of financial knowledge. ${ }^{98}$

98 It is worth noting that in a single cross-section, we cannot separate age from cohort effects. Moreover, our analysis is at a single point in time-2015and respondents in our survey may have switched groups prior to the time at which they respond. Because the NFCS is not a panel data set, we cannot follow the same individual over time. 
TABLE 2A: Financial Literacy Measures for Individuals Younger than 40 Years

\begin{tabular}{rcccccc}
\hline \hline $\begin{array}{c}\text { Variables } \\
\text { (weighted } \\
\text { mean) }\end{array}$ & $\begin{array}{c}\text { (1) } \\
\text { investive } \\
\text { financial } \\
\text { markets or } \\
\text { ret. savings }\end{array}$ & $\begin{array}{c}\text { Active in } \\
\text { retirement } \\
\text { savings }\end{array}$ & $\begin{array}{c}\text { (3) } \\
\text { Active } \\
\text { investors } \\
\text { in } \\
\text { financial } \\
\text { market }\end{array}$ & $\begin{array}{c}\text { (4) } \\
\text { Workplace- } \\
\text { only } \\
\text { investors }\end{array}$ & $\begin{array}{c}\text { (5) } \\
\text { Investor } \\
\text { population }\end{array}$ & $\begin{array}{c}\text { (6) } \\
\text { General } \\
\text { population }\end{array}$ \\
\hline $\begin{array}{r}\text { Financial } \\
\text { literacy }\end{array}$ & & & & & & \\
$\begin{array}{r}\text { Big Three } \\
\text { correct } \\
\text { Risk }\end{array}$ & 0.3737 & 0.3710 & 0.3797 & 0.2998 & 0.3520 & 0.2586 \\
$\begin{array}{r}\text { diversification } \\
\text { Asset/Bond }\end{array}$ & 0.3297 & 0.3353 & 0.3416 & 0.2340 & 0.3017 & 0.2313 \\
pricing & 0.5384 & 0.5496 & 0.4404 & 0.5141 & 0.4148 \\
Interest \\
comp.
\end{tabular}

Source: 2015 National Financial Capability Study.

Note: Sample restricted to non-retired individuals age 25-40; all estimates are weighted. Some of the averages for the financial literacy variables are lower in column 1 versus column 2 or 3 because there is an overlap between the two investor groups. As expected, the financial literacy of the overlapping group is higher compared to the level of those who belong to one investor group only. The Big Three financial literacy measure is a dummy variable with value 1 if the respondent answered the interest, inflation, and risk diversification questions correctly. 
TABLE 2B: Financial Literacy Measures for Individuals Older than 40 Years

\begin{tabular}{|c|c|c|c|c|c|c|}
\hline $\begin{array}{c}\text { Variables } \\
\text { (weighted } \\
\text { mean) }\end{array}$ & $\begin{array}{c}11) \\
\text { Active } \\
\text { investor in } \\
\text { financial } \\
\text { markets or } \\
\text { ret. savings }\end{array}$ & $\begin{array}{c}\text { (2) } \\
\text { Active in } \\
\text { retirement } \\
\text { savings }\end{array}$ & $\begin{array}{c}\text { (3) } \\
\text { Active } \\
\text { investors } \\
\text { in } \\
\text { financial } \\
\text { market }\end{array}$ & $\begin{array}{c}\text { (4) } \\
\text { Workplace- } \\
\text { only } \\
\text { investors }\end{array}$ & $\begin{array}{c}\text { (5) } \\
\text { Investor } \\
\text { population }\end{array}$ & $\begin{array}{c}(6) \\
\text { General } \\
\text { population }\end{array}$ \\
\hline \multicolumn{7}{|l|}{$\begin{array}{l}\text { Financial } \\
\text { literacy }\end{array}$} \\
\hline $\begin{array}{l}\text { Big Three } \\
\text { correct }\end{array}$ & 0.5497 & 0.5651 & 0.5779 & 0.4209 & 0.5139 & 0.3865 \\
\hline $\begin{array}{r}\text { Risk } \\
\text { diversification }\end{array}$ & 0.6754 & 0.6912 & 0.7077 & 0.5492 & 0.6403 & 0.5109 \\
\hline $\begin{array}{l}\text { Asset/Bond } \\
\text { pricing }\end{array}$ & 0.4320 & 0.4520 & 0.4726 & 0.2839 & 0.3909 & 0.3114 \\
\hline $\begin{array}{l}\text { Interest } \\
\text { comp. }\end{array}$ & 0.4295 & 0.4339 & 0.4418 & 0.3264 & 0.4009 & 0.3276 \\
\hline Mortgage & 0.8874 & 0.8963 & 0.8898 & 0.8876 & 0.8874 & 0.7945 \\
\hline Inflation & 0.7886 & 0.7897 & 0.7946 & 0.7203 & 0.7696 & 0.6813 \\
\hline Observations & 3,604 & 2,904 & 2,560 & 1,307 & 4,911 & 7,936 \\
\hline
\end{tabular}

Source: 2015 National Financial Capability Study.

Note: Sample restricted to non-retired individuals age 41-60; all estimates are weighted. The averages for the financial literacy variables are lower in column 1 versus column 2 or 3 because there is an overlap between the two investor groups. As expected, the financial literacy of the overlapping group is higher compared to the level of those who belong to one investor group only. The Big Three financial literacy measure is a dummy variable with value 1 if the respondent answered the interest, inflation, and risk diversification questions correctly.

Table 3 reports the results of regression analyses in which we analyze different investor types taking into consideration their different demographic characteristics and levels of financial literacy. ${ }^{99}$ Several findings stand out. First, financial literacy continues to be associated with a higher likelihood of being an active investor, even after controlling for many demographic characteristics, including age and education. Financial sophistication in particular-for example knowing about asset pricing-is associated with being an active investor and not a workplace-only investor (note that the estimates of this financial literacy measure change sign across investor types; i.e., those who know about basic asset pricing are less likely to be a workplace-only investor and more likely to have both retirement accounts they set up themselves and other financial investments).

99 We are aware that the classification of investors is not exogenous but the result of choice and, moreover, that some variables, such as financial literacy, can be considered endogenous. However, this is simply a descriptive analysis and does not purport to address causation. 
TABLE 3: Regression Results Across Investor Groups

\begin{tabular}{|c|c|c|c|c|}
\hline $\begin{array}{c}\text { Variables } \\
\text { (weighted mean) }\end{array}$ & $\begin{array}{c}1) \\
\text { Active investor in } \\
\text { financial markets } \\
\text { or ret. savings }\end{array}$ & $\begin{array}{c}(2) \\
\text { Active in } \\
\text { retirement } \\
\text { savings }\end{array}$ & $\begin{array}{c}\text { (3) } \\
\begin{array}{c}\text { Active investors } \\
\text { in financial } \\
\text { market }\end{array}\end{array}$ & $\begin{array}{c}\text { (4) } \\
\text { Workplace- } \\
\text { only investors }\end{array}$ \\
\hline \multirow[t]{2}{*}{ Risk diversification } & $0.091^{* * *}$ & $0.068^{* * *}$ & $0.071^{* * *}$ & $0.012^{*}$ \\
\hline & $(0.008)$ & $(0.008)$ & $(0.007)$ & $(0.007)$ \\
\hline Asset/Bond pricing & $0.088^{* * *}$ & $\begin{array}{c}0.084^{* * *} \\
(0.008)\end{array}$ & $\begin{array}{c}0.093^{* * *} \\
(0.008)\end{array}$ & $\begin{array}{c}-0.029 * * * \\
(0.007)\end{array}$ \\
\hline Interest comp. & $\begin{array}{c}0.067^{* * *} \\
(0.008)\end{array}$ & $\begin{array}{c}0.055^{* * *} \\
(0.008)\end{array}$ & $\begin{array}{l}(0.008) \\
0.046^{* * *} \\
(0.007)\end{array}$ & $\begin{array}{l}10.007) \\
-0.003 \\
(0.007)\end{array}$ \\
\hline \multicolumn{5}{|l|}{ Gender } \\
\hline Female & $\begin{array}{l}-0.045^{* * *} \\
(0.007)\end{array}$ & $\begin{array}{l}-0.016^{* *} \\
(0.007)\end{array}$ & $\begin{array}{l}-0.063^{* * *} \\
(0.007)\end{array}$ & $\begin{array}{c}0.009 \\
(0.006)\end{array}$ \\
\hline \multicolumn{5}{|l|}{ Ethnicity (BL: White) } \\
\hline Black & $\begin{array}{c}0.001 \\
(0.011)\end{array}$ & $\begin{array}{l}-0.011 \\
(0.011)\end{array}$ & $\begin{array}{c}0.002 \\
(0.011)\end{array}$ & $\begin{array}{c}0.009 \\
(0.010)\end{array}$ \\
\hline Hispanic & $\begin{array}{l}-0.004 \\
(0.010)\end{array}$ & $\begin{array}{l}-0.002 \\
(0.010)\end{array}$ & $\begin{array}{c}0.001 \\
(0.009)\end{array}$ & $\begin{array}{l}-0.022^{* * *} \\
(0.008)\end{array}$ \\
\hline Asian & $\begin{array}{c}0.063^{* * *} \\
(0.016)\end{array}$ & $\begin{array}{c}0.077^{* * *} \\
(0.015)\end{array}$ & $\begin{array}{c}0.075^{* * *} \\
(0.015)\end{array}$ & $\begin{array}{l}-0.038^{* * * *} \\
(0.013)\end{array}$ \\
\hline Other & $\begin{array}{l}-0.036 \\
(0.024)\end{array}$ & $\begin{array}{l}-0.036 \\
(0.023)\end{array}$ & $\begin{array}{l}-0.018 \\
(0.023)\end{array}$ & $\begin{array}{c}0.015 \\
(0.020)\end{array}$ \\
\hline \multicolumn{5}{|l|}{ Age (BL: 25-34) } \\
\hline $35-49$ years & $\begin{array}{l}-0.023^{* *} \\
(0.009)\end{array}$ & $\begin{array}{c}0.006 \\
(0.009)\end{array}$ & $\begin{array}{l}-0.032^{* * * *} \\
(0.008)\end{array}$ & $\begin{array}{c}0.008 \\
(0.007)\end{array}$ \\
\hline $50-60$ years & $\begin{array}{c}0.057^{* * *} \\
(0.009)\end{array}$ & $\begin{array}{c}0.084^{* * * *} \\
(0.009)\end{array}$ & $\begin{array}{c}0.006 \\
(0.009)\end{array}$ & $\begin{array}{l}-0.020^{* *} \\
(0.008)\end{array}$ \\
\hline \multicolumn{5}{|l|}{ Income (BL: <\$25,000) } \\
\hline$\$ 25,000-\$ 49,000$ & $\begin{array}{c}0.107^{* * *} \\
(0.011)\end{array}$ & $\begin{array}{c}0.075^{* * *} \\
(0.011)\end{array}$ & $\begin{array}{c}0.062^{* * *} \\
(0.010)\end{array}$ & $\begin{array}{c}0.120^{* * * *} \\
(0.009)\end{array}$ \\
\hline$\$ 50,000-\$ 99,000$ & $\begin{array}{c}0.271^{* * *} \\
(0.011)\end{array}$ & $\begin{array}{c}0.203^{* * *} \\
(0.011)\end{array}$ & $\begin{array}{c}0.201^{* * *} \\
(0.011)\end{array}$ & $\begin{array}{c}0.170^{* * *} \\
(0.009)\end{array}$ \\
\hline Over $\$ 100,000$ & $\begin{array}{c}0.414^{* * *} \\
(0.013)\end{array}$ & $\begin{array}{c}0.336^{* * *} \\
(0.013)\end{array}$ & $\begin{array}{c}0.350^{* * *} \\
(0.013)\end{array}$ & $\begin{array}{c}0.137^{* * *} \\
(0.011)\end{array}$ \\
\hline \multicolumn{5}{|c|}{ Education (BL: High school or less) } \\
\hline Some college & $\begin{array}{c}0.049^{* * *} \\
(0.009)\end{array}$ & $\begin{array}{c}0.032^{* * *} \\
(0.009)\end{array}$ & $\begin{array}{c}0.032^{* * *} \\
(0.009)\end{array}$ & $\begin{array}{c}0.031^{* * *} \\
(0.008)\end{array}$ \\
\hline $\begin{array}{r}\text { College graduate or } \\
\text { above }\end{array}$ & $\begin{array}{c}0.181^{* * *} \\
(0.010)\end{array}$ & $\begin{array}{c}0.157^{* * *} \\
(0.010)\end{array}$ & $\begin{array}{c}0.135^{* * *} \\
(0.010)\end{array}$ & $\begin{array}{c}-0.019 * * \\
(0.009)\end{array}$ \\
\hline \multicolumn{5}{|l|}{ Marital status } \\
\hline Married & $\begin{array}{c}0.028^{* * *} \\
(0.008)\end{array}$ & $\begin{array}{c}0.031^{* * *} \\
(0.008)\end{array}$ & $\begin{array}{l}0.019^{* *} \\
(0.008)\end{array}$ & $\begin{array}{c}0.021^{* * *} \\
(0.007)\end{array}$ \\
\hline \multicolumn{5}{|l|}{ Employment } \\
\hline Unemployed & $\begin{array}{l}-0.067^{* * *} \\
(0.014)\end{array}$ & $\begin{array}{l}-0.040^{* * *} \\
(0.013)\end{array}$ & $\begin{array}{l}-0.060^{* * *} \\
(0.013)\end{array}$ & $\begin{array}{l}-0.048^{* * *} \\
(0.012)\end{array}$ \\
\hline Constant & $\begin{array}{c}0.043^{* * * *} \\
(0.013) \\
\end{array}$ & $\begin{array}{l}-0.015 \\
(0.012) \\
\end{array}$ & $\begin{array}{c}0.051^{* * * *} \\
(0.012) \\
\end{array}$ & $\begin{array}{c}0.039 * * * \\
(0.011) \\
\end{array}$ \\
\hline Observations & 14,640 & 14,640 & 14,640 & 14,640 \\
\hline R-squared & 0.246 & 0.195 & 0.199 & 0.042 \\
\hline
\end{tabular}

Source: 2015 National Financial Capability Study.

Note: Sample restricted to non-retired individuals age 25-60; all estimates are weighted. Married is a dummy variable taking the value 1 if the respondent is married, but not divorced, separated or widowed, and 0 otherwise. Income brackets report household annual income from all sources, such as wages, tips, investment income, public assistance, and retirement plans. The abbreviation BL 
stands for baseline, which is the reference group. Robust standard errors in parentheses.

${ }^{* * *} \mathrm{p}<0.01,{ }^{* *} \mathrm{p}<0.05,{ }^{*} \mathrm{p}<0.1$.

In addition, several demographic variables play an important role. We find, unsurprisingly, an education divide when it comes to investing. Those with college or higher degrees are much more likely to be active investors, both in retirement savings and other financial investments, and are less likely to be workplace-only investors. Importantly, however, both general education and specialized financial knowledge matter for investment behavior; there is an independent effect of financial literacy even after controlling for education. Second, women are much less likely to be active investors both in retirement and other financial investments. ${ }^{100}$ Third, individuals with higher income are more likely to be investors, both workplaceonly and active ones, but the effect estimate is particularly large for being active investors for those with income greater than $\$ 100,000$.

Finally, the effect of age appears to vary. Older investors who are below 50 are less likely to be active investors, while in the 50 to 60 age range, they are less likely to be workplace-only investors and instead are more likely to have other retirement accounts. We suspect that this age effect is the product of the evolution of employer-based retirement savings plans described above-some participants over 50 may already have changed jobs (even several times) and, upon leaving their employer, rolled their former $401(\mathrm{k})$ savings over into an IRA. In addition, the oldest participants in our survey may have defined benefit rather than defined contribution plans and have other financial investments.

To better understand these findings and their implications, we turn to additional information, which is summarized in Figure 1. The NFCS asks survey participants if they were offered

100 This finding is consistent with other research reporting a persistent gender gap in financial literacy. See, e.g., Gary Mottola, Gender, Generation and Financial Knowledge: A Six-Year Perspective, FINRA InV. Educ. Found. InSIGHTS: FIn. CAPABILITY (March 2018), https://www.usfinancialcapability.org/downloads/Issue-Brief-Gender-Generation-and-Financial-Knowledge-A-Six-Year-Perspective.pdf [https://perma.cc/3XHX-XMU7] (finding that NFCS data reveal a persistent financial literacy gender gap between 2009 and 2015). Commentators have suggested women may be less exposed to financial education through the workplace. See Dawn Doebler, 12 Reasons Women Need to Close the Financial Literacy Gap, WTOP (Sept. 5, 2018, 5:01 AM), https://wtop.com/business-finance/2018/09/12-reasons-women-need-to-close-the-financial-literacy-gap/ [https://perma.cc/CX6F-J7LL]. Importantly, however, our findings suggest that women's exposure to $401(\mathrm{k})$ plans does not address the gender gap. 
financial education either in school or college or in their workplace. Not surprisingly, we find that workplace-only investors were much less likely to be exposed to financial education (Figure 1). Only about 30\% of workplace-only investors were offered financial education versus about $45 \%$ of all other investors. This may explain their lower levels of financial literacy and also why these low levels of financial knowledge persist until an older age.

FIGURE 1: Financial Education Offered in School or the Workplace Across Investor Groups

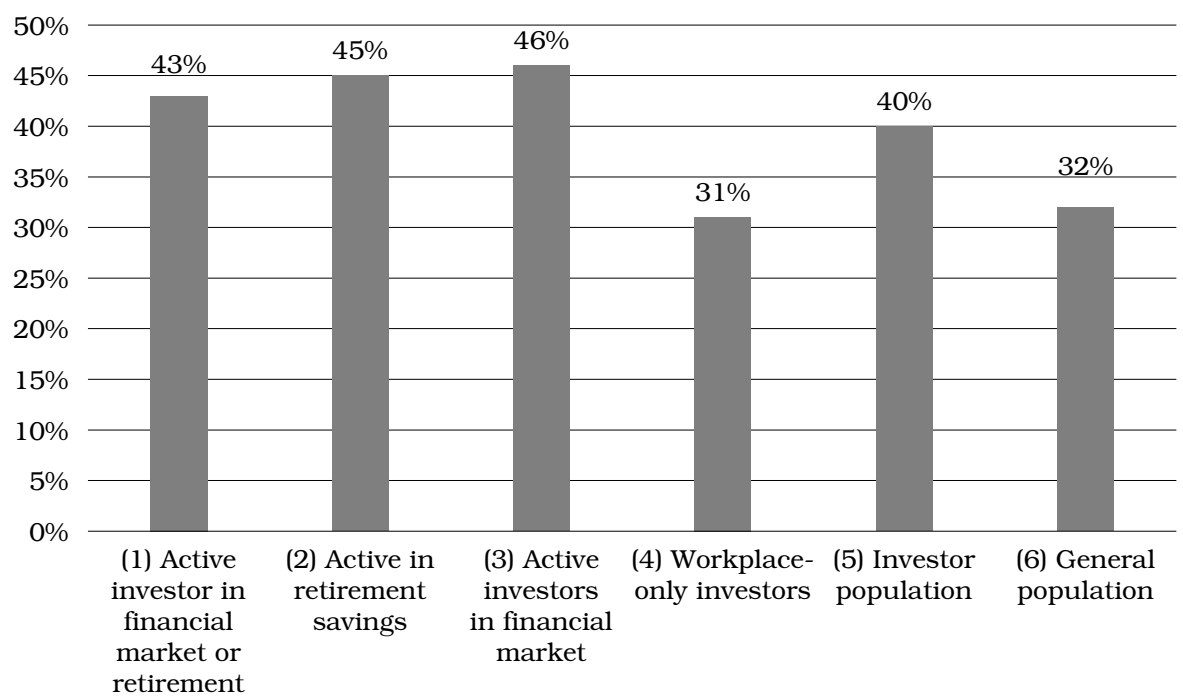

Source: 2015 National Financial Capability Study.

Note: Sample restricted to non-retired individuals age 25-60; all estimates are weighted. The numbers in the figure represent the percentages of investors who were offered financial education. The percentages are shown in relation to the particular investor sample (for example, $31 \%$ of workplace-only investors were offered financial education). In order to keep the investor samples consistent across the various analyses in this paper, the "do not know" and "prefer not to say" responses to the financial education question are not excluded from the investor samples. The exact question asked to measure who were offered financial education is "Was financial education offered by a school or college you attended, or a workplace where you were employed?"

We examine next some proxies for personal finances and personal financial management to assess whether workplaceonly investors are also less attentive when it comes to other financial decisions. This is important because other decisions about personal finances, not just retirement savings, can influence whether individuals can achieve a secure retirement. The results are reported in Table 4 . In Table $4 \mathrm{a}$, we report the list of assets and liabilities that workplace-only and active investors 
hold, and, in Table $4 \mathrm{~b}$, we report some proxies for financial management.

TABLE 4A: Assets and Liabilities Across Investor Groups

\begin{tabular}{|c|c|c|c|c|c|c|}
\hline & $\begin{array}{c}\text { (1) } \\
\text { Active } \\
\text { investor in } \\
\text { financial } \\
\text { markets or } \\
\text { ret. } \\
\text { savings }\end{array}$ & $\begin{array}{c}\text { (2) } \\
\text { Active in } \\
\text { retirement } \\
\text { savings }\end{array}$ & $\begin{array}{c}\text { (3) } \\
\text { Active } \\
\text { investors } \\
\text { in } \\
\text { financial } \\
\text { market }\end{array}$ & $\begin{array}{c}(4) \\
\text { Workplace- } \\
\text { only } \\
\text { investors }\end{array}$ & $\begin{array}{c}\text { (5) } \\
\text { Investor } \\
\text { population }\end{array}$ & $\begin{array}{c}\text { (6) } \\
\text { Total } \\
\text { population }\end{array}$ \\
\hline \multicolumn{7}{|l|}{ Assets } \\
\hline $\begin{array}{l}\text { Has a } \\
\text { checking or } \\
\text { savings } \\
\text { account }\end{array}$ & $99.22 \%$ & $99.15 \%$ & $99.55 \%$ & $98.39 \%$ & $98.98 \%$ & $93.49 \%$ \\
\hline $\begin{array}{l}\text { Has a } \\
\text { retirement } \\
\text { account }\end{array}$ & $93.08 \%$ & $100 \%$ & $90.60 \%$ & $100 \%$ & $95.05 \%$ & $61.82 \%$ \\
\hline Owns a home & $78.01 \%$ & $80.24 \%$ & $79.90 \%$ & $64.96 \%$ & $74.29 \%$ & $59.42 \%$ \\
\hline \multicolumn{7}{|l|}{ Liabilities } \\
\hline $\begin{array}{l}\text { Has credit } \\
\text { card debt* }\end{array}$ & $46.09 \%$ & $44.27 \%$ & $44.08 \%$ & $64.80 \%$ & $51.11 \%$ & $53.70 \%$ \\
\hline $\begin{array}{l}\text { Has an auto } \\
\text { loan }\end{array}$ & $42.88 \%$ & $43.67 \%$ & $43.57 \%$ & $50.29 \%$ & $44.99 \%$ & $35.65 \%$ \\
\hline $\begin{array}{l}\text { Has a student } \\
\text { loan }\end{array}$ & $31.78 \%$ & $31.13 \%$ & $32.56 \%$ & $37.28 \%$ & $33.35 \%$ & $31.46 \%$ \\
\hline $\begin{array}{l}\text { Has a home } \\
\text { mortgage* }\end{array}$ & $70.64 \%$ & $71.96 \%$ & $69.66 \%$ & $77.23 \%$ & $72.28 \%$ & $68.13 \%$ \\
\hline Observations & 6,322 & 4,892 & 4,574 & 2,459 & 8,781 & 14,640 \\
\hline
\end{tabular}

Source: 2015 National Financial Capability Study.

Note: Sample restricted to non-retired individuals age 25-60; all estimates are weighted. The variable "has a retirement account" refers to both employer-sponsored plans and private retirement accounts. Variables with an asterisk indicate that the statistics are conditional on having the related asset. The total number of observations relate to the statistics of the variables without asterisk. In order to keep the investor samples consistent across the various analyses in this paper, the "do not know" and "prefer not to say" responses to the asset and liability questions are not excluded from the investor samples. 


\section{TABLE 4B: Management of Personal Finances Across Investor Groups}

\begin{tabular}{|c|c|c|c|c|c|c|}
\hline & $\begin{array}{c}\text { (1) } \\
\text { Active } \\
\text { investor in } \\
\text { financial } \\
\text { markets or } \\
\text { ret. } \\
\text { savings }\end{array}$ & $\begin{array}{c}(2) \\
\text { Active in } \\
\text { retirement } \\
\text { savings }\end{array}$ & $\begin{array}{c}\text { (3) } \\
\text { Active } \\
\text { investors } \\
\text { in } \\
\text { financial } \\
\text { market }\end{array}$ & $\begin{array}{c}(4) \\
\text { Workplace- } \\
\text { only } \\
\text { investors }\end{array}$ & $\begin{array}{c}\text { (5) } \\
\text { Investor } \\
\text { population }\end{array}$ & $\begin{array}{c}\text { (6) } \\
\text { Total } \\
\text { population }\end{array}$ \\
\hline \multicolumn{7}{|c|}{ Checking account mgmt. } \\
\hline $\begin{array}{l}\text { Occasionally } \\
\text { overdraws } \\
\text { checking } \\
\text { accounts* }\end{array}$ & $19.94 \%$ & $19.65 \%$ & $21.79 \%$ & $24.87 \%$ & $21.34 \%$ & $22.30 \%$ \\
\hline \multicolumn{7}{|c|}{ Credit card mgmt. } \\
\hline $\begin{array}{l}\text { Has made only } \\
\text { the minimum } \\
\text { payment* }\end{array}$ & $27.87 \%$ & $26.29 \%$ & $27.18 \%$ & $46.28 \%$ & $32.80 \%$ & $38.10 \%$ \\
\hline $\begin{array}{l}\text { Charged a fee } \\
\text { for late } \\
\text { payment* }\end{array}$ & $14.16 \%$ & $14.57 \%$ & $14.54 \%$ & $17.07 \%$ & $14.94 \%$ & $16.43 \%$ \\
\hline $\begin{array}{l}\text { Charged an } \\
\text { over-the-limit } \\
\text { fee* }\end{array}$ & $9.88 \%$ & $11.20 \%$ & $10.98 \%$ & $7.51 \%$ & $9.24 \%$ & $9.39 \%$ \\
\hline $\begin{array}{l}\text { Charged fee for } \\
\text { cash advances* }\end{array}$ & $12.85 \%$ & $12.80 \%$ & $13.70 \%$ & $12.03 \%$ & $12.63 \%$ & $12.55 \%$ \\
\hline $\begin{array}{l}\text { Demonstrated } \\
\text { at least one } \\
\text { expensive } \\
\text { behavior* }\end{array}$ & $35.96 \%$ & $34.07 \%$ & $35.47 \%$ & $51.16 \%$ & $40.03 \%$ & $44.73 \%$ \\
\hline \multicolumn{7}{|c|}{ Retirement savings mgmt. } \\
\hline Took a loan* & $15.11 \%$ & $16.06 \%$ & $17.34 \%$ & $11.24 \%$ & $13.92 \%$ & $13.92 \%$ \\
\hline $\begin{array}{l}\text { Made a } \\
\text { hardship } \\
\text { withdrawal* }^{*}\end{array}$ & $12.43 \%$ & $13.63 \%$ & $14.71 \%$ & $6.19 \%$ & $10.52 \%$ & $10.52 \%$ \\
\hline $\begin{array}{l}\text { Made some } \\
\text { form of } \\
\text { withdrawal* }^{*}\end{array}$ & $18.08 \%$ & $18.97 \%$ & $20.04 \%$ & $14.38 \%$ & $16.94 \%$ & $16.94 \%$ \\
\hline \multicolumn{7}{|c|}{ Use of alternative financial services } \\
\hline $\begin{array}{l}\text { Used at least } \\
\text { one form of } \\
\text { alternative } \\
\text { financial } \\
\text { services }\end{array}$ & $24.22 \%$ & $23.49 \%$ & $26.02 \%$ & $26.20 \%$ & $24.78 \%$ & $29.31 \%$ \\
\hline Observations & 6,322 & 4,892 & 4,574 & 2,459 & 8,781 & 14,640 \\
\hline
\end{tabular}

Source: 2015 National Financial Capability Study.

Note: Sample restricted to non-retired individuals age 25-60; all estimates are weighted. All variables related to managing personal finances refer to the past year except for the use of alternative financial services which refers to the past 5 years. Alternative financial services include auto title loans, payday loans, pawn shops, and rent-to-own stores. The variables related to retirement savings refer to both employersponsored plans and private retirement accounts. Variables with an asterisk indicate that the statistics are conditional on having the related asset. The total number of observations relate to the statistics of the variables without asterisk. In order to keep the investor samples consistent across the various analyses in this paper, the "do not know" and "prefer not to say" responses to the questions used to construct the variables in the table are not excluded from the investor samples. 
There are some noteworthy findings here as well to understand the differences between workplace-only investors and other investors. Workplace-only investors are less likely to own assets, such as a house, than active investors. They are also substantially more likely than active investors to be in debt and carry different types of debt, from student loans to mortgages (if they own a home), to auto loans. When it comes to debt, the financial situation of workplace-only investors appears, in the ways measured here, to be worse than even the general population.

Workplace-only investors are also particularly likely to carry credit card debt, which is a concern because of the higher rate of interest typically associated with credit card debt. To better consider the management of credit cards, in Table $4 \mathrm{~b}$ we look at what one of us has dubbed expensive credit card behavior, i.e., paying the minimum only, going over the limit, using the card for a cash advance, and paying fees for late payments. ${ }^{101}$ What we find is that workplace-only investors exhibit a behavior that is conducive to paying high interest rates and fees on credit cards.

A variety of additional evidence suggests that workplaceonly investors are less likely to be financially savvy, more likely to face liquidity constraints, or both. About a quarter of workplace-only investors overdraw from their checking accounts. A quarter of them also use alternative financial services, such as payday loans, auto title loans, pawn shops or rent-to-own shops, which charge very high interest rates, often well above $100 \%$. Interestingly, workplace-only investors are less likely to borrow against their retirement accounts, for example taking out a loan or making a hardship withdrawal, even though borrowing from a retirement account is likely to involve lower costs than using alternative financial services or borrowing using credit cards.

In sum, our results demonstrate that workplace-only investors differ from other, more active investors not just in financial decisions with respect to their retirement accounts but also in financial decisions related to the management of their assets and liabilities. Debt, in particular, is a concern as workplace-only investors carry different types of debt, some of which charges high rates of interest. This evidence speaks of the importance for financial education, in particular for workplaceonly investors, a topic that we address in Part V below.

101 See Annamaria Lusardi \& Peter Tufano, Debt Literacy, Financial Experiences, and Overindebtedness, 14 J. PENSION ECON. \& FIN. 332, 349 (2015). 


\section{IV}

\section{IMPLICATIONS OF FINANCIAL ILLITERACY FOR 401(K) \\ INVESTING}

As the foregoing discussion demonstrates, U.S. retirement savings has evolved into a system that imposes substantial responsibility on individual employees to determine how much to save and how to invest that money. Our results pose several critical challenges for such a system. First, as noted above, financial illiteracy impedes plan participants' ability to determine what is the best use of $401(\mathrm{k})$ plan, for example, how to invest their savings. ERISA explicitly relies on employee choice as the basis for limiting the employers' fiduciary responsibilities with respect to defined contribution plans, ${ }^{102}$ but limited financial literacy suggests a level of incapacity that renders true employee choice illusory.

Historically, the ERISA standard has relied heavily on the importance of participant choice. Employer responsibility under ERISA's fiduciary standard is limited, so long as the employer offers participants reasonable investment options. ${ }^{103}$ The financial illiteracy of plan participants raises questions about their ability to exercise reasonable choice, however. If plan participants lack the ability to distinguish between investment options and reject inferior or inappropriate choices, it is arguably problematic for a plan to include those choices, and it may not be reasonable for courts or regulators to accept a plan merely on the basis that it contains some high-quality options. ${ }^{104}$ In addition, the literature has demonstrated that, probably because of low financial literacy, the menu of investment options offered by a plan can affect participant decisions-menus matter. ${ }^{105}$

On the other hand, excessive judicial scrutiny of plan composition raises a competing set of issues. If the employer has an obligation to choose what is, in its view, the most appropriate investments for its employees, that role substantially erodes participant choice, which is the bedrock of the defined

102 Employee Retirement Income Security Act, 29 U.S.C. § 1104(c) (2018).

103 See, e.g., Renfro v. Unisys Corp., 671 F.3d 314, 325-27 (3d Cir. 2011) (highlighting the relevance of the reasonableness of available investment options when evaluating a claim for breach of fiduciary duty under ERISA).

104 See Ayres \& Curtis, supra note 55, at 1504-05 (describing inferior funds as "dominated funds" and arguing that it is a potential breach of an employer's fiduciary duty to include dominated funds in a $401(\mathrm{k})$ plan).

105 Ian Ayres, Menus Matter, 73 U. CHI. L. REv. 3, 4-5, 8 (2006). 
contribution model. ${ }^{106}$ Moreover, there are a variety of reasons to prefer a choice-preserving approach, including the inability of courts, regulators, and employers to determine accurately the best interests of plan participants. ${ }^{107}$

These concerns are magnified in the context of plans that, as a practical matter, rely primarily on paternalistic employer choices rather than actual participant choice. With auto-enrollment and auto-escalation and default investment options, employers are the ones deciding whether their employees will save for retirement, how much they will save, and how that money should be invested. In these plans, the employee effectively has decisions about whether and how to invest made for him or her. Although employees can, in theory, reject their employers' decisions, financially illiterate plan participants are poorly positioned to do so. These innovations in the structure of $401(\mathrm{k})$ plans thus raise the question of the extent of an employer's obligation to validate the choices made for its employees. ERISA's fiction that employees can protect themselves from bad or inappropriate choices by opting out seems particularly inapposite. Indeed, opt ins are designed to alleviate inaction by employees; this inaction is likely to limit opt out as well, which refutes the proposition that a failure to opt out reflects an informed choice by the employee.

Moreover, while paternalistic responses such as auto-enrollment may provide a partial solution to financial illiteracy by causing a higher percentage of employees to save for retirement and by defaulting them into a reasonable investment option, they focus employers primarily on their employees' initial enrollment and investment decisions. The limited ability of plan participants to navigate the challenges of retirement investing has implications that extend beyond those initial decisions, however.

One concern is that, over the course of a plan participant's career, they may need to adjust the amount that they save for retirement or the manner in which they invest that savings. The stickiness of defaults such as savings amounts and target date fund investments may suggest to employees that the structure of the plan is consistent with their individual inter-

106 But see Bubb \& Pildes, supra note 60, at 1601 (arguing that, where participants are unlikely to act in a welfare-maximizing manner, deference to their choice is inappropriate).

107 See, e.g., Cass R. Sunstein, Nudges vs. Shoves, 127 HARV. L. REV. F. 210, 211 (2013-2014) (identifying a variety of reasons for preferring a choice-based approach to a mandate). 
ests. But the use of defaults is premised on the assumption that employees can determine whether the defaults are appropriate, and in many cases, the low levels of financial literacy suggest they cannot. Auto-escalation provisions respond to the stickiness of the initial default but may increase the employee's willingness to defer to the automatic components of the plan and may lead to an increase in debt, reducing the increase in net savings.

The problem that one size does not fit all with respect to retirement savings heightens this concern. Although it may be relatively straightforward to design a reasonable default strategy for entry-level employees, many of which are young, have limited savings, may carry student loans, and can be expected to work for thirty or forty years, the situations of plan participants become more varied as they age. Their health, financial status and debt obligations, sources of income, dependents, and other factors affect the appropriate savings rate and level of risk in their retirement accounts. Paternalism that defaults employees into a generic retirement plan without providing them with the tools to determine if adjustments to that default are appropriate may do little to help workers and may even hurt them. ${ }^{108}$ As discussed in more detail later, employees frequently change employers, and employers face today a heterogeneous population of employees.

A second and perhaps greater concern is that, to the extent that participants are successful in accumulating a large balance for retirement in their $401(\mathrm{k})$ plans, they then become responsible for deciding what to do with that money when retiring or changing jobs. Nothing in the existing regulatory structure creates a role for the employer in assisting its employees with decisions about how to use that account balance to fund their retirement, including deciding whether to roll over the account, determining how much to withdraw and figuring out how to invest what is, for most retirees, more money than they have ever been responsible before. ${ }^{109}$ As early plan participants begin to retire, their experiences are highlighting new vulnerabilities including the risk that they will be persuaded to roll their $401(\mathrm{k})$ assets over into an account that charges them

108 The high proportion of Americans carrying high-cost debt is one reason for concern about policies that focus on only one component of people's financial wellbeing.

109 Zelinksy, supra note 37, at 456-57 ("Typically the distribution from a defined contribution plan today takes the form of a single lump sum payout of the employee's account balance rather than an annuity or other periodic distribution spread over time."). 
substantially higher fees, 110 the risk that they will be persuaded to invest in unsuitable products that they do not understand, and the risk that they will be the victims of outright fraud. ${ }^{111}$

IRA rollovers offer an example of the challenges faced by 401(k) plan participants, challenges that are exacerbated by financial illiteracy. Upon retirement, a 401(k) participant typically has the choice of whether to keep their money in their employer's plan or to roll it over into an individual retirement account or IRA. An IRA allows the retiree access to the services of professional financial adviser as well as, in most case, a greater variety of investment options than are available in a typical 401(k) plan. ${ }^{112}$ In most cases, however, IRAs also involve higher fees. ${ }^{113}$

In any given case, the decision to roll over a 401(k) account depends in part on whether the higher fees associated with the IRA are cost-justified in terms of the retiree's access to better advice or products. But IRAs are particularly problematic in that the primary source of information on this trade-off is the outside adviser, whose compensation depends on whether he or she is successful in persuading the retiree to roll the money over. ${ }^{114}$ The adviser is therefore subject to a serious conflict of interest, which is magnified by the economic importance of rollovers to the financial services industry; the vast majority of the money in IRA accounts is not additional money that customers have saved independently but rather money that has been rolled over from a $401(\mathrm{k})$ account. ${ }^{115}$

110 See Luis A. Aguilar, U.S. Sec. \& Exch. Comm., Speech at the Am. Retirement Initiative's Winter 2014 Summit: Protecting the Financial Future of Seniors and Retirees (Feb. 4, 2014), https://www.sec.gov/news/speech/2014spch020414laa [https://perma.cc/AYL8-PG89] (warning that "the SEC will examine the sales practices of investment advisers that are targeting retirement-age workers to rollover their employer-sponsored 401(k) plans into higher cost investments").

111 See Marguerite DeLiema, Martha Deevy, Annamaria Lusardi \& Olivia S. Mitchell, Financial Fraud Among Older Americans: Evidence and Implications, 75 J. Gerontology Series B: PSyChOl. SCI. \& SoC. SCI. 861 (2020).

112 See John A. Turner, The Pension Mis-Selling Scandal, the SEC, and the Fiduciary Standard, 23 ConN. INS. L.J. 263, 269-71 (2016).

113 See, e.g., Anne Tergesen \& Anna Prior, The New Regulatory Hurdle for IRAs, WALL ST. J. (Mar. 27, 2016), https://www.wsj.com/articles/iras-have-a-regulatory-headache-coming-1459108346 [https://perma.cc/QT6N-AA3B] (noting that IRAs often hold higher fee investments than $401(\mathrm{k})$ plans); Turner, supra note 112 , at 263 (comparing fees associated with $401(\mathrm{k})$ plans with those commonly paid for IRAs).

114 See Turner, supra note 112, at 265-66.

115 Tergesen \& Prior, supra note 113 (observing that "rollovers now account for more than $90 \%$ of the money flowing into IRAs each year"). 
In the face of this conflict, financially illiterate employees are particularly at risk. Some financial advisers have taken advantage of this vulnerability-offering retirees bonuses and free products as incentives to roll over their $401(\mathrm{k})$ plans, ${ }^{116}$ the value of which are dwarfed by the high fees that the adviser subsequently collects on the account. ${ }^{117}$

Existing evidence suggests that a substantial number of people are moving money from their employer-sponsored plans into higher cost alternatives, ${ }^{118}$ but whether those alternatives are beneficial remains unclear. This is an important consideration because it is not always the case that financially illiterate employees follow the path of least resistance-in this case staying in the employer sponsored plans-when becoming the target of unscrupulous financial advisers. The concern is sufficient that the DOL's now-defunct fiduciary rule ${ }^{119}$ dealt specifically with rollovers, both requiring an investment adviser to obtain information prior to recommending a rollover and applying a fiduciary standard to the adviser's recommendation.

Retirees will also face the decision of whether to withdraw the money from retirement accounts as a lump sum, to make withdrawals on a periodic or as-needed basis, or to invest in

116 See, e.g., Kevin Mercadante, These 5 Brokers Will Pay You to Rollover Your IRA, MONEYUNDER30 (May 25, 2017), https://www.moneyunder30.com/ira-rollover-promotions [https://perma.cc/FR5G-64LA] (last modified Oct. 17, 2019) (describing cash incentives offered by six brokers to persuade investors to roll over the assets in their $401(\mathrm{k})$ accounts).

117 See Anne Tergesen, Be Wary of Financial Firms' 401(k) Rollover Advice, MARKETWATCH (Dec. 4, 2014), https://www.marketwatch.com/story/be-wary-offinancial-firms-401k-rollover-advice-2014-12-04 [https://perma.cc/D2QWSHE2] (observing that "many participants in 401(k) plans-particularly those in plans sponsored by large companies, which frequently offer bargain-priced institutional funds-could be shortchanged by switching to an IRA").

118 IRA assets are projected to increase to $\$ 12.6$ trillion by 2022 , and the overwhelming majority of IRA contributions currently are the result of rollovers from 401(k) plans. See Greg Iacurci, IRA Assets Will Almost Double Those in 401(k) Plans Over Next Five Years, INV. NEWs (June 25, 2018), https:// www.investmentnews.com/article/20180625/FREE/180629951/ira-assets-willalmost-double-those-in-401-k-plans-over-next-five [https://perma.cc/7KSV7Z6B].

119 In 2016, the Department of Labor adopted the Fiduciary Rule. Definition of the Term "Fiduciary"; Conflict of Interest Rule-Retirement Investment Advice (Final Fiduciary Definition), 81 Fed. Reg. 20,946 (Apr. 8, 2016). Subsequently, a federal court invalidated the rule in Chamber of Commerce v. U.S. Dept. of Labor, 885 F.3d 360 (5th Cir. 2018). Following the ruling, the US Department of Labor announced that it did not intend to enforce the rule. U.S. DEP'T OF LABOR, FIELD ASSISTANCE BULLETIN No. 2018-02 (May 7, 2018), https://www.dol.gov/agencies/ ebsa/employers-and-advisers /guidance/field-assistance-bulletins/2018-02 [https://perma.cc/3H32-WRXA]. 
annuities, which are complex financial products. ${ }^{120}$ These are areas where the adoption of defaults or automatic enrollment cannot easily be implemented as a substitute for participant choice. In particular, the determination of which of these options is preferable depends on a personalized analysis of an individual's financial condition. In addition, a number of these decisions such as the decision to roll money over into an IRA or to purchase an annuity are costly or impossible to reverse. ${ }^{121}$

Finally, for those simply changing jobs, they have to decide what to do with their accumulated retirement savings. This may involve managing multiple retirement accounts from different employers. An employee may also need to analyze, in light of their retirement plan from their prior employer, how to make the current employer's policy for enrollment, contributions, and investment in retirement accounts fit their specific needs.

\section{$\mathrm{V}$ \\ IMPROVING RETIREMENT INVESTING THROUGH 401(K) PLANS}

As the foregoing parts have detailed, the financial literacy of workplace-only investors threatens the effectiveness of a participant-directed approach to retirement savings. This part identifies two possible responses. In subpart V.A we consider increasing employer responsibility for the appropriateness of their 401(k) programs. Alternatively, in subpart V.B we evaluate the potential for employers to address the deficiencies in their employees' financial literacy through financial education programs.

120 See, e.g., Christine Lazaro \& Benjamin P. Edwards, The Fragmented Regulation of Investment Advice: A Call for Harmonization, 4 Mich. Bus. \& ENTREPRENEURIAL L. REV. 47, 71 (2014) (observing that "annuities have grown more complex" and describing various types of annuities).

121 Most annuities are subject to a substantial surrender charge if the purchase seeks to cash in the policy early, that is, prior to the end of a designated "surrender period." In addition, because of their complexity and the distribution channels through which they are sold, fraudulent practices are common. See Joseph H. Aughtman, The Annuity Conundrum: Responding to the Abuse of Elderly Investors, 38 BRIEF 38, 39 (2008) ("[W]ith a frequency that is disturbing, annuities are being used as instruments to defraud investors."); Fischler v. Amsouth Bancorporation, 1996 U.S. Dist. LEXIS 17670, at *6 (M.D. Fla. Nov. 14, 1996) (rejecting motion to dismiss securities fraud claim based on failure to disclose the surrender charge in connection with the sale of an annuity). 
A. Employer Responsibility as a Substitute for Employee Financial Literacy

One possible solution to the financial illiteracy of involuntary investors is to place greater responsibility on employers to ensure that their employees are investing appropriately for retirement. The limited fiduciary responsibilities imposed by ERISA, which rely on participant control, may be inappropriate in an environment in which participants are unable to exercise effective control and rely, directly or indirectly, on their employers to protect their interests. In this context, traditional fiduciary duties rather than judicial deference to employee judgment may be appropriate.

Greater employer responsibility could take several forms. Congress could narrow or eliminate the ERISA safe harbor for participant-directed plans. The courts could modify their interpretation of the existing safe harbor and reject the argument that participant choice is an adequate remedy for poor plan menus or the inclusion of high cost funds. As an alternative to a hard-to-apply fiduciary standard, ERISA could impose more detailed requirements concerning the structure of $401(\mathrm{k})$ plans. For example, the Department of Labor could validate particular investment options as suitable for inclusion in a 401(k) plan based on factors such as cost, asset mix, and risk. ${ }^{122}$

ERISA could also require employers to oversee or ensure the appropriateness of the choices made by their employees. It could impose an obligation on employers to ensure that employees met minimum savings thresholds, through mechanisms such as mandating higher participation rates, requiring employer matching, or requiring employers to meet shortfalls in instances in which employees are unable to save enough through their own contributions. These obligations would extend employer responsibility beyond the standards that are currently required by ERISA and that have been the subject of recent litigation.

There are two primary obstacles to using greater employer responsibility to address the current problems with retirement

122 The Department of Labor currently does something analogous to this by approving qualified default investment alternatives for $401(\mathrm{k})$ plans that provide automatic enrollment. See EMP. BENEFITS SEC. ADMIN., U.S. DEP'T OF LABOR, FACT SHEET: DEFAUlT INVESTMENT ALTERNATIVES UNDER PARTICIPANT-DIRECTED INDIVIDUAL ACCOUNT PLANS (Sept. 2006), https://www.dol.gov/agencies/ebsa/about-ebsa/ our-activities/resource-center/fact-sheets/default-investment-alternativesunder-participant-directed-individual-account-plans [https://perma.cc/4MQY$\mathrm{N} 96 \mathrm{H}]$. 
investing. The first is the challenge of identifying a workable standard of conduct. ${ }^{123}$ As existing litigation in this area demonstrates, it is difficult to design a perfect retirement planquestions such as the choice of investment options and fee structure involve predictions about the future state of the world, predictions about employee behavior, and policy choices about the most appropriate structure to accommodate employees with different needs and preferences. A standard that critically evaluated the quality of an employer's plan design would be judicially unmanageable. As the court noted in Sweda, there are a variety of rational choices that an employer or plan administrator can make in designing a plan. ${ }^{124}$ Related is the problem that the employer's decisions will be challenged after the fact, leading to the risk of hindsight bias. The fact that some choices work out better than others with the benefit of hindsight ${ }^{125}$ or benefit some employees more than others does not make a decision unreasonable. ${ }^{126}$

The second problem with imposing greater employer responsibility is that the most likely consequence of such liability would be a substantial decrease in employers' willingness to provide retirement plans to their employees. It is important to keep in mind that employers have discretion as to whether to provide $401(\mathrm{k})$ plans as an employee benefit. Both the direct costs of meeting additional regulatory requirements and the indirect costs of liability exposure under such a regime would be substantial and would increase the costs to an employer of providing a plan. The natural result would be fewer employersponsored plans. Because many employees are unlikely to save adequately for retirement outside an employer-sponsored plan, a decline in the availability of employer plans could reduce overall retirement savings, and the cost of insufficient savings would eventually be borne by taxpayers generally.

123 Cf. Anita K. Krug, The Other Securities Regulator: A Case Study in Regulatory Damage, 92 TUL. L. REV. 339, 356-61 (2017) (identifying problems with applying the standard of conduct contemplated by the Department of Labor's Fiduciary Rule to advisers' relationships with their retirement customers).

124 See Sweda v. Univ. of Pa., No. 16-4329, 2017 U.S. Dist. LEXIS 153958, at *4-7 (E.D. Pa. Sept. 27, 2017).

125 In addition, as the Sweda court observed, the fact that a plan's investments underperform the market is not an indication of inappropriate decisionmaking. Standard statistics would predict that half of all investments would underperform the median. Id. at *29-30.

126 See, e.g., Tussey v. ABB, Inc., 746 F.3d 327, 338 (8th Cir. 2014) ("While it is easy to pick an investment option in retrospect (buy Apple Inc. at \$7 a share in December 2000 and short Enron Corp. at \$90 a share), selecting an investment beforehand is difficult."). 
Similarly, it would be problematic to impose liability on employers that implement auto-enrollment or auto-escalation features. The evidence indicates that these features lead to higher rates of employee participation, and employees are clearly better off saving for retirement than not. To the extent regulatory changes are warranted, they should be directed at enabling plan participants to navigate the retirement planning process more effectively, not penalizing employers for responding to financial illiteracy in an imperfect manner. Accordingly, we argue that mandated employer-based literacy education rather than heightened employer liability is the appropriate response to financial illiteracy, a response that we develop in the next section.

\section{B. Formalizing the Employer's Role in Evaluating and Remediating Financial Illiteracy by Plan Participants}

Existing levels of financial literacy undermine the theory of participant choice upon which ERISA's current approach to defined contribution plans is based. Our data show that a substantial percentage of plan participants are financially illiterate and that, in a sense, many participants are victims of a regulatory structure that requires them to manage critical decisions regarding retirement planning without preparing them to make those decisions competently. The solution, we suggest, is for ERISA or the Department of Labor to mandate financial education, as a component of employer provided defined contribution plans.

\section{The Importance of Financial Literacy for Appropriate Retirement Savings and Investment}

Research on financial literacy points to the importance of financial knowledge for savvy investment and other behavior. Many studies, not just in the United States but around the world, show there is a strong effect of financial literacy both on whether individuals invest in stocks ${ }^{127}$ and on the return they earn on their portfolios; those who are more financially literate are more likely to invest in the stock market and to earn a

127 See generally Joanne Yoong, Financial Illiteracy and Stock Market Participation: Evidence from the RAND American Life Panel, in FINANCIAL LITERACY: IMPLICATIONS FOR RETIREMENT SECURITY AND THE FINANCIAL MARKETPLACE 76 (Olivia S. Mitchell \& Annamaria Lusardi eds., 2011) (discussing relationship between financial literacy and stock market participation). 
higher rate of return, controlling for risk. ${ }^{128}$ Financial literacy also affects portfolio choices; those who are more financially literate are more likely to invest in ways that minimize fees and avoid extreme positions (for example investing 0\% or 100\% of their portfolio in risky assets, such as stocks or stock mutual funds). ${ }^{129}$

Financial literacy is also linked to responsible behavior related to retirement savings. Specifically, those who are more financially literate are more likely to plan for retirement. ${ }^{130}$ This is consequential for retirement savings because those who plan for retirement accumulate two to three times more wealth than nonplanners. ${ }^{131}$ Those who are more financially literate are also less likely to withdraw from their retirement accounts, making it more likely that employees get to retirement with higher amounts of retirement savings. ${ }^{132}$

Financial literacy is also linked not only to long-term savings, but to short-term savings as well, such as precautionary savings which increases an investor's ability to face a financial shock. For example, those who are more financially literate are more likely to be able to come up with money if an unexpected shock were to hit, and less likely to rely on borrowing, including tapping into their retirement accounts. ${ }^{133}$

Financial literacy is linked to another important aspect of behavior, i.e., debt and debt management. This is important because, as mentioned above, retirement savings and debt are found to be closely linked, and those who have more retirement savings also have more debt. Recent research shows that those who are less financially literate are more likely to carry debt close to retirement when, in fact, people should be close to the

128 See Robert Clark et al., Financial Knowledge and 401(k) Investment Performance: A Case Study, 16 J. PEnsion ECON. \& Fin. 324, 357 (2017).

129 See, e.g., Fisch et al., supra note 5, at 637 (using experimental evidence to show that "financially illiterate investors allocate too little money to equity, engage in naive diversification, fail to identify dominated funds, and are inattentive to fees." (footnote omitted)).

130 See Lusardi \& Mitchell, supra note 6, at 518.

131 Annamaria Lusardi \& Olivia Mitchell, Financial Literacy and Planning: Implications for Retirement Well-Being, in FINANCIAL LITERACY, supra note 127, at 17.

132 See Ashley Ann Tharayil \& William B. Walstad, The Effect of Financial Literacy on Withdrawing Funds Intended for Retirement-Conclusions Drawn from Three Years of Data 15-18 (Jan. 4, 2019) (unpublished manuscript) (Am. Econ. Ass'n Paper Session).

133 See ANDREA HASLER, ANNAMARIA LUSARDI \& NOEMI OgGERO, FINANCIAL FRAGILITY IN THE US: EVIDENCE AND IMPLICATIONS 9-10 (Apr. 2018), https://gflec.org/wp-con tent/uploads/2018/04/Financial-Fragility-Research-Paper-04-16-2018-Final. pdf?x37292 [https://perma.cc/GQ58-WVTN]. 
peak of their wealth accumulation. ${ }^{134}$ Most importantly, financial illiteracy is found to be closely linked to poor debt management, such as behavior associated with paying high interest costs, fees and going over pre-set borrowing limits. ${ }^{135}$ It has also been associated with using high-cost methods of borrowing, such as relying on payday loans or using pawn shops, methods that charge interest rates often well above $100 \% .{ }^{136}$

It is certainly difficult to distinguish causality from correlation, and one can argue that both financial literacy and active investing are the products of individual investor choice; in other words, individuals can invest in both knowledge and financial assets. However, studies that have addressed the issue of causality have shown not only that the causality runs from financial literacy to financial behavior (rather than the other way around), but also that the original estimates that did not account for the endogeneity of financial literacy may have led to an underestimation of the effects of financial literacy on saving, investment, and planning behavior. ${ }^{137}$ Simply stated, it is hard to imagine that ignorance is bliss when it comes to investment, and that employees could get to the right investment for them without having any knowledge of the basic principles of finance. And financial ignorance, in particular of the concepts related to investment decisions, is well documented in all of the studies we have reviewed.

Empirical estimates notwithstanding, theoretical models of saving also highlight the critical importance of financial literacy. If, as empirical studies show, financial literacy allows individuals to participate in financial markets and earn a higher rate of return on their investments than nonliterate individuals, the effects on retirement savings are very consequential. According to the estimates of Lusardi, Michaud, and Mitchell, financial literacy can account for 30 to $40 \%$ of the inequality of retirement savings as employees approach retirement. ${ }^{138}$

134 See Annamaria Lusardi et al., The Changing Face of Debt and Financial Fragility at Older Ages, 108 AM. ECON. Ass'N PAPERS \& PROCEEDINGS 407, 407 (2018).

135 See Lusardi \& Tufano, supra note 101, at 349.

136 See Annamaria Lusardi \& Carlo de Bassa Scheresberg, Financial Literacy and High-Cost Borrowing in the United States 12-14 (Nat'l Bureau of Econ. Res., Working Paper No. 18969, 2013).

137 See Lusardi \& Mitchell, supra note 3, at 27.

138 Annamaria Lusardi et al., Optimal Financial Knowledge and Wealth Inequality, 125 J. POL. ECON. 431, 433 (2017). 
2. The Role of Financial Education in Improving Financial Literacy

Another way to understand the importance of financial literacy is to examine the effects of programs designed to boost financial knowledge. Several states in the United States have made financial literacy mandatory in high school. ${ }^{139}$ Financial education programs are also provided in colleges and universities $^{140}$ and the workplace. ${ }^{141}$

Measuring the effectiveness of financial education programs is complex because a number of confounding factors can affect how participants respond to these programs. ${ }^{142}$ For example, selection issues may confound the results-those who attend may be disproportionately motivated or, alternatively, the least financially literate. One way of addressing these issues is through randomized controlled trials (RCT), which are considered the gold standard of evaluations. ${ }^{143}$

Early studies found limited effects from financial education programs, leading some to conclude that there was no value to financial education. ${ }^{144}$ In some cases this might have been due to the details of the programs, which often cannot be assessed,

139 According to the most recent Council for Economic Education's Survey of the States, seventeen states require high school students to take a course in personal finance. COUNCIL FOR ECON. EdUC., SURVEY OF THE STATES, ECONOMIC AND PERSONAL FINANCE IN OUR NATION'S SCHOOLS (2018), http://www.councilforeconed. org/wp-content/uploads/2018/02/2018-SOS-Layout-18.pdf [https:// perma.cc/GY4P-DKV5].

140 See, e.g., Ted Beck, How to Help Colleges Teach Financial Literacy, WALL ST. J. (Aug. 6, 2017), https://blogs.wsj.com/experts/2017/08/06/how-to-help-col leges-teach-financial-literacy/ [https://perma.cc/TNR9-HPXY] (observing that "[n]ow there are literally hundreds of institutions taking responsibility" for financial education).

141 See, e.g., Chloe Skaar, More Companies Are Offering Financial Education for Employees, COlumBus DisPaTCH (June 28, 2018, 6:44 PM), https://www.dispatch. com/business/20180628/more-companies-are-offering-financial-education-foremployees [https://perma.cc/HC2X-NQGB] (reporting that employers are increasingly offering financial education programs to their employees).

142 See Justine S. Hastings, Brigitte C. Madrian \& William L. Skimmyhorn, Financial Literacy, Financial Education and Economic Outcomes, 5 ANN. REv. ECON. 347, 359-61 (2013) (observing that the existing literature on the effects of financial education programs is mixed and inconclusive and that "this literature needs additional large-scale randomized interventions designed to effectively identify causal effects").

143 See, e.g., Tim Kaiser \& Lukas Menkhoff, Does Financial Education Impact Financial Literacy and Financial Behavior, and if So, When?, 31 WORLD BANK ECON. REV. 611, 615-17 (2017) (observing that studies involving RCTs show highly significant effects of financial education on financial behavior).

144 See Daniel Fernandes, John G. Lynch Jr. \& Richard G. Netemeyer, Financial Literacy, Financial Education, and Downstream Financial Behaviors, 60 MGMT. SCI. 1861, 1862 (2014). 
because the majority of studies lack specific program information about, for example, quality of the material, program intensity, and teacher training. ${ }^{145}$ In addition, studies often aggregated the results across the entire group of participants without considering the possibility that the programs could have affected particular groups differently, such as those who were the least financially literate. A recent comprehensive meta-analysis of the effects of financial education shows that not only do financial education programs work, but also that the details of the programs matter substantially. ${ }^{146}$

Recent work on financial education also shows that implementation is critically important. ${ }^{147}$ For example, financial education in school is found to be most effective when financial education is a required course with a rigorous curriculum and where the teachers are trained to teach financial literacy. ${ }^{148}$ While these findings are hardly surprising, they confirm that evaluations of the effect of financial education need to be rigorous and take into account the characteristics and quality of the program as well as the well-documented differences in financial literacy across demographic groups. The importance of financial literacy in school is also confirmed by the mounting evidence that is now emerging around the world; many studies have found similar and even stronger effects of financial education in school in other countries. ${ }^{149}$ Further indirect evidence of its importance is that, since 2012, the OECD has added financial literacy to the topics it measures in its Programme for International Student Assessment (PISA), assessing the readiness of high school students around the world. ${ }^{150}$

145 See, e.g., Wendy L. Way \& Karen C. Holden, Teachers' Background and Capacity to Teach Personal Finance: Results of a National Study, 20 J. FIN. CounSELING \& PLAN. 64, 66-75 (2009) (examining data from more than 1,200 K-12 teachers, prospective teachers, and teacher education faculty representing four census regions and finding that fewer than one-fifth stated they were prepared to teach personal finance).

146 See Kaiser \& Menkhoff, supra note 143, at 626-28.

147 Carly Urban, Maximilian Schmeiser, J. Michael Collins \& Alexandra Brown, State Financial Education Mandates: It's All in the Implementation, FINRA INV. EDU. Found. (Jan. 2015), https://www.finra.org/sites/default/files/investoreducationfoundation.pdf [https://perma.cc/9535-APWY].

148 Carly Urban et al., The Effects of High School Personal Financial Education Policies on Financial Behavior, ECON. EDUC. REV. (2018), https://doi.org/ 10.1016/j.econedurev.2018.03.006 [https://perma.cc/U8PE-9WNV].

149 Verónica Frisancho, The Impact of School-Based Financial Education on High School Students and Their Teachers: Experimental Evidence from Peru 3-4 (Inter-Am. Dev. Bank, Working Paper No. 871, 2018).

150 Launch: OECD PISA Financial Literacy Assessment of Students, ORG. ECON. CO-OPERATION \& DEV., https://www.oecd.org/daf/fin/financial-education/ 
Some studies have assessed the effectiveness of financial education in the workplace. Studies here are more heterogeneous, and many programs have not been evaluated or evaluated rigorously, but the existing evidence shows that financial education in the workplace holds much promise. ${ }^{151}$ In the following subpart we elaborate from the research findings and our own experience working with both firms and financial market regulators to offer some initial components of an effective employer-provided financial education program.

\section{Key Components of Employer-Provided Financial Education}

The existing research points to three components of an effective employer-provided financial education program that could be implemented by all employers: (1) a self-assessment, (2) minimum requirements about the content of programs, and (3) timing-when the program and components of the programs should be provided.

Starting with the first, we recommend that employers be required to provide a self-assessment enabling their employees to measure their financial knowledge and capability. We now have validated ways to measure financial literacy-a set of questions has been tested in many national surveys and has provided robust findings. ${ }^{152}$ An assessment can serve several purposes; it could be the first step toward segmenting workers into different types of financial education programs targeted to different needs and different levels of financial knowledge. It could also provide a simple way for both employer and employees to be informed and track progress over time. A self-assessment also makes it possible for those who can demonstrate financial knowledge to opt out of simple programs or participate only in parts of the program. Self-assessments could extend to financial behavior, in addition to financial knowledge, and become a financial check-up that employees can take to assess the state of their finances on a regular basis.

launch-pisa-financial-literacy-students-2017.htm [https://perma.cc/KR39K44Z].

151 See Kaiser \& Menkhoff, supra note 143, at 612 (providing meta-analysis of 126 studies of financial education and concluding that the studies are highly heterogeneous but generally support the idea that financial education, including education done in the workplace, can be effective).

152 Some large firms are already using financial literacy questions, such as the Big Three, to measure financial knowledge among their employees. See Lusardi \& Mitchell, supra note 94, at 498-99. 
Second, as for the program content, the Department of Labor could introduce minimum requirements as to what should be included in a program to provide the working knowledge and skills necessary to navigate the defined contribution system. ${ }^{153}$ These requirements could include both specific information about the $401(\mathrm{k})$ plan, the investment options contained in that plan, and the process of saving and investing for retirement. They could also extend to more general components of personal financial decision-making that contribute to an employee's financial well-being.

Academic research indicates that effective financial education programs should extend beyond retirement savings or investing, ${ }^{154}$ because poor financial decisions of all kinds can influence retirement savings both directly and indirectly. For example, an employee's decision to purchase a house or automobile and to incur debt in connection with that purchase can affect how much that employee can contribute to a retirement account, because debt is one of the most important reasons why employees do not contribute to supplementary retirement accounts. ${ }^{155}$ Given the cost and prevalence of high cost borrowing and the potential mismanagement of debt, programs that include debt and debt management can be particularly important. Moreover, lack of precautionary savings may lead individuals to tap into retirement accounts prematurely when they experience financial shocks, making it important for education programs to promote both long-term and short-term savings. ${ }^{156}$

The existing research shows that there are many ways in which financial education can be provided, for example through on-line programs, videos, or live sessions, either in individualized or group formats. ${ }^{157}$ These programs are often

153 The P-Fin Index illustrates the eight areas of working knowledge and what employees know the least. PAUL J. YAKOBOSKI, ANNAMARIA LUSARDI \& ANDREA HASLER, THE 2018 TIAA InstituTE-GFLEC PERsonal FinANCE IndeX, THE STATE OF FinANCIAL LITERACY AMONG U.S. ADULTS 1 (Apr. 2018), https://gflec.org/wp-content/ uploads/2018/04/TIAA_GFLEC_Report_PFinIndex_April2018_fin.pdf?x98192 [https://perma.cc/BR5W-YXQK].

154 See Hastings et al., supra note 142, at 358.

155 See Rajashri Chakrabarti et al., Household Debt and Saving During the 2007 Recession 13 (Nat'l Bureau of Econ. Research, Working Paper No. 16999, 2011), https://www.nber.org/papers/w16999.pdf [https://perma.cc/B5UBGCMW] (explaining that those who decreased net contributions to their retirement accounts were motivated to reduce debt).

156 About one-third of Americans could not come up with \$2,000 in a month, if they were to face an unexpected need. HASLER ET AL., supra note 133, at 3.

157 Aileen Heinberg et al., Five Steps to Planning Success: Experimental Evidence from U.S. Households, 30 OXFORD REV. ECON. POL'Y 697, 699-701 (2014). 
simple, yet effective and not costly. For example, initiatives like those described in the Five Steps to Planning Success, which teaches the basics of financial planning in short videos, have been found to have an effect on financial knowledge. ${ }^{158} \mathrm{Re}-$ search also shows that some topics, such as risk and risk diversification, are particularly hard for employees to grasp, 159 but that simple tools that help people visualize and simplify the workings of risk and risk diversification have an effect on financial knowledge. ${ }^{160}$

In addition, programs can be made more effective if tailored to the needs of specific employees. For example, young workers may benefit from programs covering student loans and buying the first home. Women may benefit from programs about investing and saving for the long term. ${ }^{161}$ Older workers may benefit from programs about Social Security, when it is best to withdraw Social Security benefits, and the workings of annuities. Older workers may also benefit from programs specially focused on retirement planning such as financial calculators that demonstrate the impact of withdrawals from $401(\mathrm{k})$ plans on projected retirement security over time.

Studies also show that employees are demanding financial education and view the provision of financial education in the workplace positively. ${ }^{162}$ For many, workplace-provided programs are the only source of financial education to which they are exposed. Even so, employee motivation to participate in financial education programs can be increased through incentives. ${ }^{163}$ Employers can offer employees financial incentives for participating in education programs, performance-based incentives such as rewards for success on tests of financial liter-

158 Id. at 708-15.

159 See YAKOBOSKI ET AL., supra note 153, at 1 (discussing a personal finance index as a robust measure of overall personal finance knowledge and a nuanced analysis of knowledge across different areas of personal finance in which individuals inherently function).

160 Annamaria Lusardi et al., Visual Tools and Narratives: New Ways to Improve Financial Literacy, 16 J. PENSION ECON. \& FIN. 297, 312-15 (2015).

161 As shown earlier, women are those more likely to be passive investors. See supra note 100 and accompanying text.

162 Rebecca Estrada, Best Practices for Workplace Financial Education, InT'L Found. EMP. BENEFIT PlANS (Sept. 12, 2018), https://blog.ifebp.org/index.php/ financial-education-workplace-best-practices [https://perma.cc/85M2-PCAL].

163 See generally Providing Incentives for Your Employee Financial Wellness Program, ENRICH (July 17, 2018), https://www.enrich.org/blog/employee-financial-wellness-program-incentives [https://perma.cc/5M8M-YRME] (describing potential incentives to increase employee use of workplace financial education programs). 
acy, as well as rewards for demonstrating healthy financial behaviors over time.

Importantly, an employer-provided financial education program should be independent in the sense that it should not steer employees to a particular investment option (particularly one that provides fees to the sponsor or source of the education program). ${ }^{164}$ It is also important to make sure that programs teach or enable employees to make financial decisions, rather than preach what is suitable behavior, according to the employer's perspective. ${ }^{165}$

Third, timing of financial education programs has been shown to be extremely important. ${ }^{166}$ For example, programs could be provided at the critical moments when financial decisions are made, such as the beginning of employment, at separation, at the time of promotion, or when benefits and health benefits are reviewed (normally on a yearly basis). Timing of the programs addresses several of the issues that have been linked to the effectiveness of financial education, for example the fact that knowledge may decline with time ${ }^{167}$ and that education is most effective when it is provided at the time that people have to make decisions.

While recent research shows that many employers have an interest in providing financial education to their employees, ${ }^{168}$ the programs that are offered vary significantly. This creates

164 See Michael Kitces, Financial Literacy Effectiveness \& Providing Just-InTime Training By Financial Advisors, KITCES (Sept. 21, 2016, 7:01 AM) https:// www.kitces.com/blog/financial-literacy-program-effectiveness-just-in-timetraining-by-financial-advisors/ [https://perma.cc/F9WN-ND9L] (observing that "a significant problem with the idea of just-in-time financial education is that it will often rely on the company providing the product or service to deliver it").

165 See Sandro Ambuehl, B. Douglas Bernheim, \& Annamaria Lusardi, A Method for Evaluating the Quality of Financial Decision Making, with an Application to Financial Education 3-4 (Nat'l Bureau of Econ. Research, Working Paper No. 20618, 2017), https://www.nber.org/papers/w20618.pdf [https:// perma.cc/UV7W-5XXK].

166 See, e.g., Karina Harley, The Effects of 'Just in Time' Financial Education Programs on Financial Literacy and Economic Decision-Making in Superannuation 1, 86-87 (2017) (unpublished thesis, Wirtschaftsuniversitat Wien), http:// 47ctca2fz6ha46w 11826tujxm5k.wpengine.netdna-cdn.com/wp-content/ uploads/sites/15/2017/05/Harley-Thesis_Impact-of-just-in-time-financial-education-intervention-on-superannuant-decision-making.pdf [https://perma.cc/ $8 \mathrm{Z} 2 \mathrm{~F}-\mathrm{C} 87 \mathrm{P}$ ) (describing the importance of providing financial education on a "just-in-time" basis).

167 See id. at 12 (noting that "[t]here is a significant body of evidence to demonstrate that financial literacy boosted by educational interventions diminishes over time").

168 See LORI LUCAS, EBRI's 2018 EMPLOYER FINANCIAL WELLBEING SURVEY 1, 2-3 (2018), https://www.ebri.org/docs/default-source/ebri-issue-brief/ebri_ib_466_ fwrcsur-29nov18.pdf?sfvrsn=bdb23e2f_6 [https://perma.cc/2ZRL-ZGKB]. 
different opportunities for employees across firms, but it also means that a number of employers offer substandard programs or do not provide any financial education at all. ${ }^{169}$ Thus, our recommendation is for the Department of Labor both to mandate employer-provided financial education and to issue a set of guidelines that govern what is considered an acceptable program, along the same lines in which they have expressed judgments on what are acceptable investment options. Additionally, guidelines on how to evaluate program success would assist employers in improving program effectiveness.

One might ask why a mandate is necessary in light of the market-based trend toward providing workplace-based financial education. We identify several advantages to a regulatory mandate. First, it would ensure that all workers, not only those working in big firms or firms providing generous pension benefits, have access to financial education in the workplace. For many and, in particular, vulnerable groups, the workplace may be the only source of financial education. Second, our proposal leaves room for firm-specific decisions about the details of their financial education, a mandate only sets a floor with respect to minimum standards. Third, a regulatory mandate encourages market-based innovation. Existing research is still experimenting to develop what works best in financial education, and a regulatory requirement provides an incentive for third party providers to invest in this area. Mandates can also bolster the exchange of information and experience across firms, improving the supply and quality of programs over time and their effectiveness in addressing the needs of workers. ${ }^{170}$

Finally, a requirement that applies to all firms is necessary to address worker mobility. Many workers change jobs during their working career. In the same way in which defined benefit plans were not an adequate pension system in a dynamic labor market, defined contribution plans that do not take into consideration the different needs of workers are not adequate for the current labor force. Using shortcuts to compensate for the absence of informed participant choice, such as automatic enrollment or default investment options, is particularly problem-

169 See id. at 12-14.

170 We note that employers rarely share the details of their programs, although such information is potentially quite valuable to assist others in designing an effective program. For an example, see Dara Duguay, Making Financial Education Work in the Workplace, FED. RES. BANK OF MINN. (Apr. 1, 2011), https:// www.minneapolisfed.org/publications/community-dividend/making-financialeducation-work-in-the-workplace-the-citigroup-experience [https://perma.cc/ 4PED-4TE9]. 
atic if employees stay with the same employer for a short period of time only. Default options do not address the knowledge required to make decisions about how to transfer retirement savings or to manage retirement savings when making job transitions.

Furthermore, the fact that inadequate retirement savings and poor investing will require taxpayers to make up for these mistakes, strengthens the case for mandates. Note that these are soft mandates; they do not require individuals to save or invest a specific amount; rather they provide the individuals with the skills to make the decisions that the new pension system requires from them.

In addition, although requiring that employers provide financial education is a burden, employers will also benefit from financial education programs because they will increase the value of the benefits programs that they provide to their employees. In turn, this will assist employers in recruiting and retaining employees. In addition, employers obtain value from worker financial wellbeing because troubling financial situations can affect employees' performance at work. ${ }^{171}$ While these benefits offer employers incentives to implement financial education programs voluntarily, making such programs mandatory will ensure that all workers can be exposed to financial education.

In summary, as studies of financial education programs have become methodologically rigorous, they have developed evidence that financial education offers much promise in addressing financial illiteracy and poor financial decision-making. Financial education programs are not only a step forward when looking at measures to equip employees to manage their own retirement accounts and invest their retirement savings but also a necessary requirement if the objective of defined contribution pensions is to promote financial security and make employees save adequately for their retirement. Further, if insufficient retirement funds strain the welfare system and, at the end, affect taxpayers, it is important to find ways to reach as large a share of employees as possible.

171 See, e.g., Kyle Sanders, Is it Time to Offer Financial Education as a Benefit?, EMP. BENEFIT ADVISOR (Dec. 1, 2017, 11:00 AM), https://www.employeebenefit adviser.com/opinion/is-it-time-to-offer-financial-education-as-a-benefit [https:/ /perma.cc/ZNE7-6YB2] (reporting that a substantial number of employees suffer from serious financial stress that interferes with their performance at work). 


\section{CONCLUSION}

The structure of U.S. retirement savings has evolved to rely critically on active participation and informed choices by participants in employer-sponsored 401(k) plans. In this Article, we present new evidence that this structure has introduced a substantial number of people to the financial markets whose only contact with those markets is their $401(\mathrm{k})$ plan and that these workplace-only investors are both different from other investors and largely unprepared to make responsible savings and investment decisions. Despite the limited financial literacy of workplace-only investors, the existing regulatory structure largely defers to employee choice to limit the responsibility of employers for the appropriateness of those decisions.

We challenge this approach, concluding from our empirical analysis that workplace-only investors are too vulnerable to take sole responsibility for their current and future financial well-being. We identify two possible regulatory responses: imposing greater responsibility on plan sponsors to oversee the quality of employees' retirement investing or requiring employers to evaluate and remediate the financial literacy of plan participants through investor education. We conclude that the latter approach is more promising and call for the Department of Labor to require employer-sponsored financial education. The financial landscape and labor markets that employees face today have changed substantially. It is time to change the regulatory framework to equip workers with the knowledge and skills they need to make informed decisions about their pensions in the twenty-first century. 


\section{Appendix:}

TABLE A1: Comparison of the General Populations Including "Do Not Know" (DNK) Responses with the General Population Excluding DNK Responses.

\begin{tabular}{|c|c|c|}
\hline $\begin{array}{c}\text { Variables } \\
\text { (weighted mean) }\end{array}$ & $\begin{array}{c}\text { (1) } \\
\text { General } \\
\text { population } \\
\text { incl. DNK }\end{array}$ & $\begin{array}{c}\text { (2) } \\
\text { General } \\
\text { population } \\
\text { excl. DNK }\end{array}$ \\
\hline Big Three correct & 0.3054 & 0.3280 \\
\hline Risk diversification & 0.4416 & 0.4669 \\
\hline Asset/Bond pricing & 0.2571 & 0.2748 \\
\hline Interest comp. & 0.3293 & 0.3416 \\
\hline Mortgage & 0.7512 & 0.7674 \\
\hline Inflation & 0.5631 & 0.5825 \\
\hline \multicolumn{3}{|l|}{ Gender } \\
\hline Male & 0.4929 & 0.5072 \\
\hline Female & 0.5071 & 0.4928 \\
\hline \multicolumn{3}{|l|}{ Ethnicity } \\
\hline White & 0.6304 & 0.6341 \\
\hline Black & 0.1197 & 0.1216 \\
\hline Hispanic & 0.1690 & 0.1661 \\
\hline Asian & 0.0569 & 0.0552 \\
\hline Other & 0.0239 & 0.0230 \\
\hline \multicolumn{3}{|l|}{ Age } \\
\hline 25-34 years & 0.2996 & 0.2915 \\
\hline 35-49 years & 0.3990 & 0.3973 \\
\hline 50-60 years & 0.3014 & 0.3111 \\
\hline \multicolumn{3}{|l|}{ Income } \\
\hline Below $\$ 25,000$ & 0.2090 & 0.2185 \\
\hline $\mathbf{\$ 2 5 , 0 0 0 - \$ 4 9 , 0 0 0}$ & 0.2517 & 0.2447 \\
\hline$\$ 50,000-\$ 99,000$ & 0.3508 & 0.3415 \\
\hline Over $\$ 100,000$ & 0.1885 & 0.1953 \\
\hline \multicolumn{3}{|l|}{ Education } \\
\hline High school or less & 0.2670 & 0.2628 \\
\hline Some college & 0.4257 & 0.4265 \\
\hline College graduate or above & 0.3074 & 0.3107 \\
\hline \multicolumn{3}{|l|}{ Marital status } \\
\hline Married & 0.5657 & 0.5515 \\
\hline Single, not married & 0.3028 & 0.3109 \\
\hline Divorced or separated & 0.1161 & 0.1213 \\
\hline Widowed & 0.0155 & 0.0163 \\
\hline \multicolumn{3}{|l|}{ Employment } \\
\hline Employed (full, part time) & 0.6315 & 0.6379 \\
\hline Self-employed & 0.0832 & 0.0863 \\
\hline Unemployed & 0.0764 & 0.0787 \\
\hline Not in the labor force & 0.2089 & 0.1971 \\
\hline Observations & 16,793 & 14,640 \\
\hline
\end{tabular}


Source: 2015 National Financial Capability Study.

Note: Sample restricted to non-retired individuals age 25-60; all estimates are weighted. The Big Three financial literacy measure is a dummy variable with value 1 if the respondent answered the interest, inflation, and risk diversification questions correctly. Income brackets report household annual income from all sources, such as wages, tips, investment income, public assistance, and retirement plans. 
DATA APPENDIX.

The National Financial Capability Study (NFCS) is the first and only survey providing detailed information about financial literacy and financial capability in the United States. The survey, which is supported by FINRA Financial Education Foundation, started in 2009 and is conducted every three years. One of the authors of this paper (Lusardi) has been the academic advisor of the survey since its inception and has participated in the design of the NFCS's questionnaire - in particular the parts related to measuring financial literacy and personal finance management. The survey is representative of the U.S. population, and the data, since 2012 , is collected online only. One of the important features of the data is the large number of observations, more than 27,000, which make it possible to study not just the total population but also specific subgroups, such as those who invest in retirement and other accounts.

To construct our sample, we used data from the latest wave of the survey, 2015. We restricted the sample to non-retired respondents in the age group 25-60 to avoid respondents who are still in school or those very close to retirement or retiring. We distinguish between different types of investors based on the questions listed below:

C1) Do you or your [spouse/partner] have any retirement plans through a current or previous employer, like a pension plan, a Thrift Savings Plan (TSP), or a 401(k)?

[Yes; No; Don't know; Prefer not to say]

C3) Are any of these retirement plans the kind where you or your [spouse/partner] get to choose how the money is invested?

[Yes, No, Don’t know, Prefer not to say]

C4) Do you or your [spouse/partner] have any other retirement accounts NOT through an employer, like an IRA, Keogh, SEP, myRA, or any other type of retirement account that you have set up yourself?

[Yes, No, Don’t know, Prefer not to say]

B14) Not including retirement accounts, does your household have any investments in stocks, bonds, mutual funds, or other securities?

[Yes, No, Don't know, Prefer not to say] 
The answers to $\mathrm{C} 4$ are used to identify participants who have set up their own retirement accounts (active investors in retirement savings). The answer to B14 are used to identify participants who have private investments other than or in addition to retirement accounts (active investors in financial markets). We used the answers to the first two questions (C1and $\mathrm{C} 3$ ) and also to $\mathrm{C} 4$ and B 14 to determine workplaceonly investors, i.e., they are those who have a retirement plan through their employer where they get to choose how the money is invested but do not have any other retirement accounts or other financial investments in stocks, bonds, mutual funds and other securities (workplace-only investors).

To construct these definitions of investors, we delete the "do not know" and "prefer not to say" responses to questions C3, C4, and B14, ${ }^{172}$ as otherwise a clear classification would not have been possible. In some cases, this has the effect of dropping a sizable number of observations, in particular when looking at the responses to $\mathrm{C} 3$ (7\% of the total working age population). This is mostly due to the frequency of "do not know" responses. This can be considered additional evidence of the lack of knowledge and information of individuals, in particular when it comes to retirement accounts. In total, we drop 2,153 observations. In Table A1, we report the demographics and average financial literacy levels of the general population with both including and excluding the "do not know responses". Overall, we do not find much evidence of selectivity when focusing on the sample without the "do not know" responses.

We report below the list of financial literacy questions available in the 2015 NFCS. The Big Three financial literacy questions refer to M6, M7 and M10.

M6) Suppose you had $\$ 100$ in a savings account and the interest rate was $2 \%$ per year. After 5 years, how much do you think you would have in the account if you left the money to grow? [More than \$102; Exactly \$102; Less than \$102; Don't know; Prefer not to say]

M7) Imagine that the interest rate on your savings account was $1 \%$ per year and inflation was $2 \%$ per year. After 1 year, how

172 We do not exclude the "do not know" and "prefer not to say" answers from question $\mathrm{C} 1$ because question $\mathrm{C} 3$, that we use in the definition of workplace-only investors, is only asked to the respondents answering "yes" to question $\mathrm{C} 1$. 
much would you be able to buy with the money in this account?

[More than today; Exactly the same; Less than today; Don't know; Prefer not to say]

M8) If interest rates rise, what will typically happen to bond prices?

[They will rise; They will fall; They will stay the same; There is no relationship between bond prices and the interest rate; Don’t know; Prefer not to say]

M31) Suppose you owe $\$ 1,000$ on a loan and the interest rate you are charged is $20 \%$ per year compounded annually. If you didn't pay anything off, at this interest rate, how many years would it take for the amount you owe to double?

[Less than 2 years; At least 2 years but less than 5 years; At least 5 years but less than 10 years; At least 10 years; Don't know; Prefer not to say]

M9) A 15-year mortgage typically requires higher monthly payments than a 30-year mortgage, but the total interest paid over the life of the loan will be less.

[True; False; Don't know; Prefer not to say]

M10) Buying a single company's stock usually provides a safer return than a stock mutual fund.

[True; False; Don't know; Prefer not to say] 